\title{
EL REY Y EL GRAN INQUISIDOR: RELIGIÓN Y POLÍTICA EN LOS ESCRITOS DE B. MONTEAGUDO Y C. HENRÍQUEZ (BUENOS AIRES, 1810-1820)*
}

\author{
POR \\ JIMENA TCHERBBIS TESTA ${ }^{1}$ \\ Universidad Torcuato Di Tella. CONICET
}

\begin{abstract}
RESUMEN
El artículo examina la relación entre política y religión durante la primera década revolucionaria del Río de la Plata a partir del análisis de la crítica a la Inquisición española por parte de quienes se aventuraron a la revolución. El análisis de las representaciones que B. Monteagudo y $\mathrm{C}$. Henríquez construyeron acerca del tribunal, y el uso político que se hicieron de las mismas en la esfera pública porteña, demuestra que la cuestión inquisitorial ocupó un lugar significativo en el pensamiento político del período revolucionario. Es que la crítica a la Inquisición, allí cuando aparece, cede lugar a la defensa de los derechos naturales del hombre conjugada con una forma de gobierno que se imagina como liberal. Pues su crítica no era un mero recurso para atacar a España, era, también, un medio para imaginar nuevas formas de articular religión y política.
\end{abstract}

PALABRAS CLAVE: revolución; Inquisición; liberal; derechos; Monteagudo; Henríquez.

\section{THE KING AND THE GRAND INQUISITOR: RELIGION AND POLITICS IN THE WRITINGS OF B. MONTEAGUDO AND C. HENRÍQUEZ (BUENOS AIRES, 1810-1820)}

\begin{abstract}
This paper examines the relation between politics and religion during the first revolutionary decade in the River Plate through the analysis of the criticism against the Spanish Inquisition made by those who ventured to the revolution. The analysis of the representations that B. Monteagudo and C. Henríquez built about the Court and how they were politically used in the Public Sphere shows that the issue of the Inquisition occupied a significant place in the political thought of the revolutionary period. It happens that the criticism against the Inquisition, when appears, gives rise to the defense of the natural rights and a form of government imagined as liberal. Therefore, the criticism was not only a resource to attack Spain, was, also, a mean to imagine new ways to articulate religion and politics.
\end{abstract}

KEY WORDS: revolution, Inquisition; liberal; Rights; Monteagudo; Henríquez.

Cómo CITAR ESTE ARTículo / CITATION: Tcherbbis Testa, J. 2017. «El rey y el gran inquisidor: religión y política en los escritos de B. Monteagudo y C. Henríquez (Buenos Aires, 1810-1820)». Hispania Sacra 69, 139: 275-292. doi: 10.3989/hs.2017.019

Recibido/Received 08-01-2016

Aceptado/Accepted 29-04-2016

\footnotetext{
*El presente trabajo forma parte de una investigación de doctorado más amplia dedicada a estudiar, en perspectiva comparada, el pensamiento liberal en la opinión pública a propósito de la crítica a la Inquisición española en Lima, Buenos Aires y Cádiz durante el período 1808-1860. Trabajo que cuenta con el financiamiento de la beca de investigación del Centro de Estudios y Documentación
}

Latinoamericanos (CEDLA), Ámsterdam, Fundación Slicher Van Bath de Jong. Se agradecen también los comentarios y sugerencias de los evaluadores anónimos de la revista.

1 jime-tt@hotmail.com / ORCID iD: http://orcid.org/0000-0002 $-2419-2655$ 
Frente al Rey y a la Inquisición... ichitón!

Refrán popular

El gran enemigo de la causa de la libertad es la superstición, es el fanatismo, es el infernal espíritu inquisitorio

El Censor, 4 de septiembre de 1817

\section{INTRODUCCIÓN}

Nos proponemos analizar la cultura política del período de la emancipación hispanoamericana centrando nuestra atención en una problemática poco visitada por la historiografía. Nos referimos a la oposición hacia la Inquisición española por parte de quienes se aventuraban a la revolución. Fue, precisamente, en el convulsionado contexto abierto por la crisis de la Monarquía Hispánica cuando surgieron las primeras representaciones liberales contra el Santo Oficio. Sucede que la cuestión inquisitorial, en la medida en que remitía a la compleja relación entre religión y política, se convirtió en un asunto clave del período.

Es que, de hecho, la propia institución de la Inquisición condensaba tensiones teológicas-políticas debido a que, a pesar de ser una autoridad delegada por el Papa, se caracterizaba por poseer un fuerte matiz monárquico. Como advirtió $\mathrm{H}$. Kamen, además de su entramado institucional que la hacía dependiente de la monarquía en lo que a nombramientos y renta respecta, la Inquisición servía a un interés religioso y a la vez político: construir obediencia entre los fieles que, se esperaba, se comportasen como súbditos. ${ }^{2}$ En el orbe hispano persistía, pues, la concepción medieval de la Cristianitas según la cual todos aquellos que tienen fe en Cristo, y obedecen a la Iglesia, forman una comunidad que debe estar sujeta a un mismo gobierno. En aquél régimen de cristiandad, como señala R. Di Stefano, las amenazas contra el poder temporal lo eran también contra la Iglesia. ${ }^{3}$

De este modo, si bien la sociedad distinguía las realidades temporales de las espirituales no las concebía como esferas separables. La religión ocupaba un rol clave en los fundamentos del orden social. En principio, porque se consideraba un elemento asociativo que estimulaba la solidaridad moral entre los hombres. Pero, además, porque constituía el mecanismo de legitimidad política a través del principio del derecho divino de los reyes. La religión ejercía así un efecto de consagración de la realidad social.

En este contexto, se desenvuelve la relación entre catolicismo y política que P. Manent denominó "problema teológico-político". ${ }^{4}$ Problema derivado de la contradicción propia de la doctrina católica basada en que si, por un lado, habilita a los hombres a organizarse en lo temporal de acuerdo a sus preferencias, por el otro aspira a vigilarlos. Es que la convicción de que la salvación de las almas se alcanza por la fe y las obras y de que la sociedad sólo es viable en la unanimidad de conciencia impulsaba a la Iglesia a ejercer un control sobre lo temporal.

\footnotetext{
2 Kamen 1985. Véase también López Vela 1990.

3 Di Stefano 2000.

4 Manent 2001: 39-54.
}

La monarquía absoluta fue la forma de gobierno que pretendió reducir a la unidad del soberano civil la dualidad del poder político y religioso. Se trataba de superar la tensión entre papado e imperio reuniendo, en palabras de Hobbes, "las dos cabezas del águila". Pero lo cierto es que, lejos de cumplir con esa intención, la religión conservó su poder político gracias a la protección que el absolutismo le otorgó. Pues, como plantea Manent, «el soberano de la era absolutista da prueba de su soberanía dando mandatos religiosos, pero subordinándose más y más a la religión debilita el motivo y el resorte de su soberanía». ${ }^{5}$

El problema teológico-político se despliega al calor de las revoluciones liberales del siglo XIX. Como advirtió C. Lefort, no podemos descifrar las transformaciones de la sociedad política decimonónica sin interrogarnos sobre su significación religiosa. ${ }^{6}$ Es preciso, pues, prestar atención a la historia política de la religión y, a la vez, a la historia religiosa de la política moderna. ${ }^{7}$ Sólo recientemente la historiografía ha abordado el problema de la relación entre política moderna y religión considerando el caso de las revoluciones del orbe hispano. Quizás se deba a que, como advierte S. Serrano, éstas fueron revoluciones políticas singulares pues transitaron de una legitimidad religiosa a una jurídica sin expulsar, en sus comienzos, la religión del Estado. ${ }^{8}$ Sin embargo, allí el problema no resultaba menor en tanto estaba también presente el dilema de qué lugar debía ocupar Dios en la ciudad de los hombres.

En este contexto, el análisis de la oposición liberal a la Inquisición puede resultar clave para reflexionar sobre la relación entre religión y política, particularmente, entre liberalismo y catolicismo en el siglo XIX. A la luz del bicentenario de la Constitución de Cádiz la historiografía ha comenzado a repensar la problemática de la crítica liberal a la Inquisición, pero lo ha hecho desde una perspectiva estrictamente peninsular. ${ }^{9}$ Perspectiva que, cuando se ha superado, no ha reparado en el caso del Río de la Plata. ${ }^{10}$

5 Manent 1993 [La traducción es nuestra]: 67.

6 Lefort 1986: 275-329.

Manent 1993: 53-74.

8 Serrano 2008: 18-19.

Nuestra propuesta comparte su interés con estos estudios. En primer lugar, existen trabajos dedicados al estudio del nacimiento de la figura del Gran Inquisidor en la literatura europea, véase Julliot 2010 y Sempere Muñoz 2008. En segundo lugar, hay trabajos que analizan el problema en la clave de la disputa por la definición de la identidad nacional española, véase Sempere Muñoz 2010 y López Vela 2005. La historiografía en esta clave para los casos hispanoamericanos es escasa. Para el caso del Santo Oficio de Lima véase Ayllón 1997 y Carvacho y Dedieu 2002. Para el caso del Santo Oficio de Nueva España véase Torres Puga 2009. A su vez, desde la perspectiva de los estudios literarios disponemos de trabajos que analizan las primeras novelas del período de la post-independencia que tienen como protagonista a la Inquisición, véase Mejías López 1999; Sarrochi Carreño 2009; De la Torre Villar 1989 y Hampe Martínez 2004.

10 El problema de la representación de la Inquisición española en el Río de la Plata no ha sido, per se, objeto de estudio en la historiografía. Desde la perspectiva de la historia de las religiones contamos con investigaciones que de modo tangencial aportan datos e interpretaciones sobre el asunto, véase Di Stefano 2007 y 2010. Los trabajos sobre la historia de la Iglesia nos permiten reconstruir el contexto en el cual las representaciones decimonónicas sobre la Inquisición, aquí analizadas, han sido elaboradas, véase Di Stefano y Zanatta 2000. Sobre la problemática de la tolerancia religiosa, Calvo 2006. Disponemos también de algunos trabajos que han examinado la cuestión religiosa en la construcción de la identidad nacional, véase Cebrelli 2000. 
El artículo se propone demostrar que la crítica al tribunal inquisitorial ocupó un lugar significativo en el pensamiento político de los revolucionarios rioplatenses. Este trabajo comparte, pues, su interés con aquellos estudios dedicados a analizar las representaciones liberales sobre la Inquisición. De modo que no se pretende aquí analizar la cuestión inquisitorial en sí misma (es decir el complejo asunto de su naturaleza jurídica, los alcances de su jurisdicción y sus tensas relaciones con los jueces eclesiásticos ordinarios o con la justicia civil) sino el modo en que la crítica liberal, conocedora de la ambigua condición del tribunal, convirtió a la Inquisición en objeto de reflexión de la nueva cultura política. Es que, como veremos, a ambos lados del Atlántico, el pensamiento liberal contraponía la Inquisición española, representada como símbolo del despotismo y fanatismo propio del Antiguo Régimen, a la lucha por un nuevo orden basado en los derechos y libertades garantizados en una constitución, entre los cuales la libertad de pensamiento y expresión eran considerados fundamentales. Pero mientras que en la Península los liberales hacían de la Inquisición una pieza clave en su lucha contra los proyectos absolutistas, en América las representaciones tenían un alcance mayor en la medida en que los revolucionarios más radicalizados hicieron del tribunal un símbolo del poder de la metrópolis. ${ }^{11}$

No es casual, entonces, que la prensa y la literatura fueran el medio privilegiado en donde se desató la crítica al Santo Oficio y se expusieron los nuevos principios políticos, herederos de la Ilustración y forjadores del naciente liberalismo hispanoamericano. Es que la crítica a la Inquisición, allí cuando aparece, cede lugar a la defensa de los derechos naturales del hombre conjugada con una forma de gobierno que se imagina como liberal. Pues, como advirtió Manent, la crítica liberal surge como una respuesta al problema teológico-político al buscar crear nuevas condiciones para la acción humana. ${ }^{12}$ Entendemos aquí al liberalismo en sentido amplio en tanto una cultura de la libertad que tuvo como principal preocupación la emancipación del hombre de las ataduras del despotismo, tal como lo plantea en sus trabajos Di Stefano. ${ }^{13}$ El liberalismo resulta ser, así, una revolución de los derechos humanos en tanto procura proteger los derechos del individuo. Como señala J. Fernández Sebastián, el liberalismo se convirtió a lo largo del siglo XIX en un concepto legitimador de las nuevas instituciones, equivalente en gran medida a la modernidad política. ${ }^{14}$ Entre aquellas nuevas prácticas y valores, la opinión pública, los derechos individuales y la constitución resultaban centrales. Así el concepto liberal/liberalismo será utilizado, en los primeros años del siglo XIX, principalmente en un sentido políticomoral. Pero el contexto de unanimidad religiosa en el que surge el liberalismo hispánico ejercerá complejas influencias en su cultura política. De modo que los emergentes

11 Se entiende por revolucionarios radicalizados a aquellos pertenecientes a la facción morenista cuya postura política, como precisa N. Goldman, se diferenció por fundamentarse en la teoría de los derechos naturales que concebía a la libertad y a la igualdad como derechos indisolubles y colocaba a la voluntad humana en el centro de la escena política, véase Goldman 2009.

12 Manent 2011.

13 Di Stefano 2012.

14 Véase Fernández Sebastián (coord.) 2012 y Jaksic y Posada Carbó 2011. principios liberales tendrán una postura ambigua respecto al catolicismo. Y es allí, pues, en la emergente esfera pública donde se delinean las filosofías de la revolución. ${ }^{15}$

En esta oportunidad analizaremos, a través del cruce disciplinar entre la historia política y cultural, las representaciones que Bernardo Monteagudo y Fray Camilo Henríquez construyeron acerca de la Inquisición y el uso político que se hicieron de las mismas en la esfera pública porteña. ${ }^{16}$ Se trata de dos políticos y publicistas que en tiempos coloniales padecieron, como muchos otros, la censura del tribunal y que participaron activamente en los procesos de independencia hispanoamericana transitando espacios que, aunque diversos, fueron compartidos.

\section{EL TRONO Y EL ALTAR EN UN ESCENARIO CAMBIANTE}

El Santo Oficio español tenía jurisdicción no sólo en la Península. Ya desde el año 1569, durante el reinado de Felipe II, se decidió instalar tribunales inquisitoriales, dependientes del Consejo General de la Suprema Inquisición, en el nuevo continente. Cada Virreinato tendrá, entonces, su propia corte inquisitorial. El Virreinato del Perú tendrá la suya, la Inquisición de Lima. ${ }^{17}$ Si bien en 1776 el Virreinato del Perú se desintegró, la Inquisición de Lima seguirá teniendo jurisdicción en el recientemente creado Virreinato del Río de la Plata. A pesar de que existieron intentos por erigir un palacio inquisitorial en Buenos Aires, el Río de la Plata no tendrá su propia corte. ${ }^{18}$ Allí la Inquisición procuraba ejercer el control a través de la itinerante figura del comisario inquisitorial. ${ }^{19}$ La acción inquisitorial en la región no resultó ser tan efectiva como en la Península. La lejanía y los problemas económicos del tribunal dificultaban el traslado de la documentación y los presos hacia el palacio limeño de modo que no todas las denuncias derivaban en procesos. A su vez, el tribunal limeño no poseía jurisdicción sobre los indígenas, que constituían parte importante de la población, y enfrentaba una mayor resistencia por parte de los obispos. ${ }^{20}$ En el Río de la Plata la represión de los delitos religiosos resultó

15 Véase Carozzi 2011.

16 Desde la década de 1980 existe un consenso entre los historiadores en torno al reconocimiento de un nuevo modo de historiar la política que reivindica la especificidad de la política como campo de estudio, véase Rosanvallon 2002; Roldán 2007 y Ternavasio 2010. Sobre la cultura política, los análisis del discurso y la historia del lenguaje político, véase Goldman (dir.) 2008 y Fernández Sebastián (dir.) 2009.

17 Sobre la historia de la institución de la Inquisición en España y Lima la literatura es extensa, remitimos al lector a las siguientes obras: Lea 1908; Toribio Medina 1956; Pérez Villanueva y Escandell Bonet (dirs.) 1984-2000; Hampe Martínez 1998; Millar Carvacho 1998; Guibovich Pérez 2013 y Martínez Millán 2007.

18 Hacia mediados del siglo XVIII existió un interés en crear un tribunal en Buenos Aires. Al respecto véase: Memorial de don Pedro de Logu al Consejo indicando la conveniencia de fundar un tribunal del Santo Oficio en el Río de la Plata, 6 de junio de 1754, en Toribio Medina 1945: 390-393.

19 Sobre el estudio de la actuación de la Inquisición específicamente en el Río de la Plata remitimos al lector a Toribio Medina 1945; Lewin 1956 y Di Stefano y Zanatta 2000: 79-84.

20 Las cifras de la actividad represiva de la Inquisición de Lima son notoriamente inferiores a las de los tribunales peninsulares. Hasta 1820, año de su abolición, fueron condenadas cerca de 1700 personas, entre las cuales 50 fueron relajadas al brazo secular. 
ser mayor en la región del noroeste pero no pocas veces era la misma justicia civil la que se encargaba de juzgarlos. ${ }^{21}$

Lo cierto es que, creada originariamente para perseguir la herejía judaizante, hacia fines del siglo xvIII el tribunal reorienta sus objetivos hacia la persecución de las luces en el contexto del llamado cordón sanitario que se construye frente a la Revolución Francesa. ${ }^{22}$ De modo que entre los delitos procesados desde antaño, como los judaizantes, el luteranismo, la blasfemia, la hechicería, la bigamia, la sodomía y las solicitaciones, comienzan a registrarse los nuevos delitos ideológicos, aquellos que R. García Cárcel caracteriza como "la tentación del pensar". ${ }^{23}$ Así lo confirman los expedientes no sólo peninsulares sino también aquellos pertenecientes al tribunal limeño. ${ }^{24}$ No sorprende, entonces, que la circulación de libros prohibidos preocupara a algunos sectores de la elite. Éste fue el caso del Deán Funes que, en ocasión de la Oración fúnebre a Carlos III de 1789, no dudaba en defender a la Inquisición como mecanismo de control frente a las nuevas ideas que amenazaban minar el poder de la Iglesia:

...esparcese un diluvio de libros impíos a quienes recomienda un bello espíritu lleno de falacia y prestigio, que ofrece vicios sin freno, culpas sin remordimiento, y penas sin expiación; y a pesar de la vigilancia de un severo tribunal encomendado del campo de nuestra fe asoma la cizaña entre el buen grano y se descubre la obra de las tinieblas. ¡Qué escándalo! La Inquisición truena: llama a su auxilio el Soberano y acude Carlos a salvar a su Pueblo con toda la firmeza que inspira la Religión: de mi persona abaxo le dice al Señor Inquisidor General, todo está sugeto a la jurisdicción de la fé. ${ }^{25}$

Fue al calor de la invasión napoleónica cuando el naciente pensamiento liberal hispano comienza a generar un intenso debate en torno al Santo Oficio. Sucede que Napoleón Bonaparte, tras llegar a Madrid, decreta el 4 de diciembre de 1808 la abolición de la Inquisición argumentando: «El tribunal de la Inquisición queda suprimido, como atentatorio a la soberanía y a la autoridad civil». ${ }^{26}$

Pero dado que ésta era una medida impulsada por las fuerzas invasoras, los diputados reunidos en las Cortes de Cádiz, que sesionarán desde 1810, no podrán desatenderse

\footnotetext{
21 Véase Vasallo 2010 y Farberman 2005.

22 Véase Elorza 1989.

23 García Cárcel, R. 1996: 252.
}

24 Si bien entre 1796 y 1818 los delitos más denunciados fueron la bigamia y la hechicería, que recaían sobre la población mayoritaria, negra y mulata, la Inquisición intentó consolidar sus prerrogativas de control ideológico en torno a la circulación de libros prohibidos. Véase: Archivo General de la Nación, Colección Andrés Lamas, Legajo $\mathrm{N}^{\circ} 33$, Impreso sobre los libros prohibidos por la Inquisición (1798). Archivo del Arzobispado de Córdoba, Legajo N¹8, Tomo 3. El acoso sobre los extranjeros y la elite lectora creaba, en palabras de V. Peralta Ruiz, "una sensación de angustia ante la posibilidad de un desprestigio social". Véase Peralta Ruiz 2002: 79.

25 Oración fúnebre que en las exequias del católico rey Don Carlos III, celebradas en esta Santa Iglesia Cathedral de Cordova del Tucumán dixo el Doctor Don Gregorio Funes, Canónigo de Merced de la misma Santa Iglesia. Buenos Ayres MDCCXC. Con el Superior permiso. En la Real Imprenta de los Niños Expósitos. Reproducción facsimilar en: Archivo del Dr. Gregorio Funes. Deán de la Santa Iglesia Catedral de Córdoba 1944, Tomo I: 333-334. Buenos Aires: Imprenta de la Biblioteca Nacional.

26 Citado en Escudero 2005: 368. del asunto y se pronunciarán al respecto. Mientras los diputados absolutistas defenderán la permanencia de la Inquisición, los liberales propondrán su abolición. ${ }^{27}$ En el contexto de su lucha contra la monarquía absoluta el discurso liberal hace de la Inquisición el símbolo del despotismo y el fanatismo impulsando la abolición del tribunal. El debate logra traspasar los muros del recinto y se desarrolla en la arena de la opinión pública a través de la prensa, los panfletos políticos y la literatura.

Si bien ya se había proclamado a la Inquisición incompatible con la Constitución, luego de intensos debates se decide formalizar la abolición del tribunal mediante un decreto sancionado el 22 de febrero de 1813. La metrópolis vive entonces su primera experiencia constitucionalista en Cádiz intentando limitar el poder del monarca, pero también el de la Iglesia, con el fin de crear un nuevo orden basado en los principios liberales de igualdad, libertad y propiedad. $Y$ en esa invención del nuevo orden, se pensaba, la Inquisición no debía existir.

No obstante, es preciso advertir que la abolición de la Inquisición no implicó la libertad de cultos. Por el contrario, en su artículo 12 la Constitución declara al Catolicismo como la religión oficial y única verdadera. Existía entonces una compleja relación entre liberalismo y catolicismo, en virtud de la cual la crítica a la Inquisición no era pensada como condena a la religión sino más bien a las prácticas políticas del trono y el altar. Sucede que, como advierte E. La Parra López, para los liberales la intolerancia no era un principio propio del catolicismo sino una prescripción del poder civil (y, si bien no se planteaba explícitamente, la consecuencia lógica era que la intolerancia no tenía que por qué ser inevitable). ${ }^{28}$ De hecho, debe advertirse que los primeros liberales fueron herederos de los principios regalistas de los ilustrados católicos quienes planteaban la necesidad de subordinar la Iglesia al Estado. En este sentido, las críticas al tribunal vehiculizaban reivindicaciones en torno a la libertad de conciencia y expresión aunque, inicialmente, no se demandara la libertad de cultos. En palabras de M. Revuelta González: «Los diputados liberales dejaban claras las premisas, pero no se atrevían a sacar la conclusión». ${ }^{29}$ El liberalismo hispánico surgió, pues, vinculado a la homogeneidad confesional. De modo que su cultura política se veía atravesada, indudablemente, por componentes religiosos. El problema era, sin embargo, cómo se plantearía esa relación. ${ }^{30}$

La coyuntura de la invasión napoleónica creó un nuevo escenario político en el que las tensiones entre la Península

27 Acerca de los debates producidos en el recinto gaditano remitimos al lector a los siguientes trabajos: Alonso Tejada 1969; Escudero 2005: 351-438; Dofour 2005 y Casado y La Parra López 2013.

28 La Parra López 2014.

29 Revuelta González 2013: 253.

30 Véase Fernández Sebastián 2011. El autor también señala que para los liberales hispánicos el catolicismo constituyó un repertorio cultural e intelectual del cual, ineludiblemente, formaban parte más que un componente ideológico. De modo que, sostiene, la confesionalidad resultaba ser una cuestión de hecho más que de opinión. Si bien las demandas iniciales se orientaban a la libertad de expresión y pensamiento, éstas resultaron ser inseparables de las controversias en torno a la tolerancia de cultos. De hecho, hasta la Restauración de Fernando VII al trono, no eran pocos los liberales que, como A. Arguelles, confiaban en que el desarrollo social facilitaría la adopción de la libertad religiosa. 
e Hispanoamérica se acrecentaron cada vez más. La ambigua condición de América en la Monarquía Hispánica, una monarquía compuesta, hacía dudar acerca del trato hacia el nuevo continente. La aceptación de América como parte esencial de España llegaría muy tarde y, aun así, sin su correlato en la igualdad de representación política. Los liberales gaditanos mostraron sus limitaciones en el reconocimiento de Hispanoamérica y gran parte de ésta optará por la revolución, que sólo tiempo más tarde derivará en la Independencia. ${ }^{31}$

Las revoluciones hispánicas no sólo transformaron la situación política en la que vivían peninsulares e hispanoamericanos sino que, fundamentalmente, reinventaron la actividad política misma. Fueron, ante todo, revoluciones políticas: impusieron un nuevo principio de legitimidad del poder al tiempo que surgieron nuevos actores dispuestos a conquistar esa legitimidad. Actores que comienzan a disociarse de su pertenencia estamental y corporativa. Como señaló T. Halperín Donghi, si bien la Revolución de Mayo nace como heredera del poder caído condenará todo su pasado hispánico al transitar el camino de la soberanía popular. ${ }^{32}$ Principio que, como plantea M. Ternavasio, genera un delicado dilema ya que la legitimidad sólo podía proceder del consentimiento de aquellos sobre los que se gobernaba. ${ }^{33}$

Los revolucionarios rioplatenses comienzan así a experimentar la difícil creación de un nuevo centro de poder político. Un aspecto importante de la politización revolucionaria es la emergencia de la prensa en la que se evidencia la utilización de un nuevo lenguaje político. ${ }^{34}$ El 20 de abril de 1811 se sanciona el primer decreto que establece la libertad de imprenta, aunque al mismo tiempo se anuncia la formación de una Junta Suprema de Censura. Este decreto, influenciado directamente por aquél que sancionaron las Cortes de Cádiz en 1810, quedará anulado cuando uno nuevo, sancionado el 26 de octubre de 1811, otorgue mayores libertades de expresión anulando la previa censura. ${ }^{35}$ La Junta de Censura es entonces reemplazada por la Junta Protectora de la Libertad de Imprenta que, en vez de castigar los abusos de la libertad, debía juzgar las restricciones a la misma. No obstante, las limitaciones se mantenían en un campo que parecía incuestionado: el religioso.

Desde su misma creación la Junta revolucionaria se propuso crear una prensa oficial que diera cuenta de los asuntos de gobierno. La Gaceta de Buenos Aires dirigida por Mariano Moreno cumplirá esa función. Sin embargo, como se sabe, al calor de la revolución seguirán creándose nuevos periódicos, aún cuando hasta 1815 existe en Buenos Aires solamente una imprenta, la de Niños expósitos. La libertad de imprenta no existió ajena a las tensiones del período. Pues, como afirma N. Goldman, existía una tensión entre: "...las iniciativas de las nuevas autoridades por instaurar y promover la controversia pública, pero al mismo tiempo controlar sus desbordes, en particular aquellos que expresaban críticas a las autoridades $» .{ }^{36}$ Sucede que, ade-

\footnotetext{
31 Véase González Bernaldo de Quirós (comp.) 2015.

32 Halperín Donghi 1985.

33 Ternavasio 2003: 57.

34 Goldman 2000.

Véase Pasino 2013

6 Goldman 2000:11.
}

más, los editores necesitaban del apoyo financiero de las autoridades para que sus periódicos lograran subsistir. $Y$ es el problema financiero el que explica el carácter efímero de muchas publicaciones.

Fue a través de las armas de papel que los revolucionarios intentaron forjar una opinión pública para ilustrar a los nuevos ciudadanos en sus derechos y deberes. Emprendían así una tarea de pedagogía política que, acudiendo a diversos recursos filosóficos, practicaba el arte de la persuasión con la firme convicción de que en la ignorancia se cimentaba el despotismo. ${ }^{37}$ Analizaremos aquí los escritos de los revolucionarios Bernardo Monteagudo y Fray Camilo Henríquez a propósito de la Inquisición difundidos en la emergente esfera pública porteña durante la década de 1810. Dos revolucionarios que, como muchos otros, padecieron la prohibición de leer aquellos libros que los inquisidores consideraban heréticos y que, sin embargo, leyeron, tradujeron y cuyas ideas se atrevieron a difundir. ${ }^{38}$

\section{REVOLUCIÓN Y RELIGIÓN: LA JURISDICCIÓN INQUISITORIAL EN JAQUE}

Al iniciarse el proceso revolucionario la Inquisición de Lima continuaba actuando, aunque, claro, no con el vigor de antaño. A modo de ejemplo, B. Lewin nos recuerda cómo el propio Mariano Moreno, en tanto secretario de la Junta de gobierno, debió acceder al pedido del Comisario del Santo Oficio en Buenos Aires, don José Francisco de la Riestra, y dictar, el 16 de julio de 1810, una orden que otorgaba «el auxilio de tres Blandengues con un cabo" para conducir a un preso de la Inquisición a Mendoza y de allí, a través de Chile, a Lima. ${ }^{39}$ En el Río de la Plata, la Inquisición fue también objeto de políticas que discutieron su abolición. Como es sabido, la crítica al fanatismo fue un tópico compartido por los revolucionarios más radicalizados, aquellos pertenecientes al grupo morenista agrupados en la Logia Lautaro. Es que, como advierte R. Di Stefano, la revolución abre un marco de legitimidad inédito para la crítica religiosa. ${ }^{40}$

Así lo demuestran las intervenciones de Monteagudo en la prensa porteña. Recordemos que aquél abogado tucumano se formó en la Universidad de Chuquisaca, período en que leyó no solo a los autores clásicos sino también a los nuevos pensadores europeos. Ya a la edad de 19 años lo encontramos participando en las revoluciones del Alto Perú, en Chuquisaca y La Paz, hecho que lo llevó a sufrir la prisión a comienzos de $1810 .{ }^{41}$ Logró, sin embargo, rápidamente fugarse gracias a la ayuda de quienes fueron sus compañeros rioplatenses en la Universidad. Es así como, trabando estrechos lazos con la campaña de Juan José Castelli en el Alto Perú, se compromete con la Revolución de Mayo trasladándose luego a la ciudad porteña. Es aquí cuando da sus primeros pasos en el grupo morenista mostrándose como un firme defensor de la declaración de la independencia y de un gobierno democrático y

37 Véase Carozzi 2011: 62.

38 Véase Santini 2012 y Villarreal Brasca 2009.

39 Lewin 1956: 7.

40 Di Stefano 2010: 79.

41 En ese contexto Monteagudo dará también sus primeros pasos con las "armas de papel" publicando el documento titulado Diálogo de Atahualpa y Fernando VII en los Campos Elíseos (1809) en el que justifica la legitimidad de la revolución americana. 
republicano. Se trata de una época de su pensamiento político que el propio Monteagudo describiera, tiempo más tarde y a la distancia, como "fiebre mental". ${ }^{42}$

Ya en sus intervenciones en la Gaceta de Buenos Aires de los días viernes, Monteagudo demostraba una pluma filosa cuando reflexionaba sobre la influencia política adversa de ciertos sectores del clero. ${ }^{43}$ En esos tiempos no dudaba en criticar a aquellos curas que no difundían la causa revolucionaria argumentando:

Con este motivo no puedo pasar en silencio la inacción, mejor diré la malicia de los curas en general, por no ilustrar a sus feligreses sobre la obligación en que están de sostener la causa de la patria; dando en conocer en esto que el fanatismo y la superstición se interesan en conservar la tiranía, así como el verdadero culto propone aniquilarla. ${ }^{44}$

Interesante es, a su vez, que en otro artículo, al comentar las acciones de Francisco Miranda, se aprovecha la ocasión para simpatizar con un caballero irlandés que aconsejaba al revolucionario caraqueño la necesidad de remover "la mayor enfermedad moral de los españoles» pronunciándose a favor de «la necesidad y la justicia del tolerantismo». ${ }^{45}$

Sucede que ganar a los religiosos para la causa revolucionaria era un objetivo fundamental, más aún para aquellos que discutían la legitimidad divina no sólo del monarca español sino también de sus derechos de posesión sobre América. Se trataba pues de distinguir las esferas para subordinar lo religioso a las nuevas exigencias de la política. La crítica al fanatismo religioso reaparece en la Oración inaugural pronunciada en la apertura de la Sociedad Patriótica en la tarde del 13 de enero de $1812 .{ }^{46}$ Allí Monteagudo relata, acudiendo a la filosofía roussoniana, los orígenes de los hombres libres que, una vez asociados, son encadenadas por los tiranos quienes «llamaron en su auxilio el fanatismo de los pueblos, y formaron un sistema exclusivo de moral, y religión que autorizaba la violencia, y usurpaba a los oprimidos hasta la voluntad de quejarse $» .{ }^{47}$ En América, afirma,

42 Sobre el itinerario político e intelectual de Monteagudo véase Herrero, F. (recop.) 2006: 9-32.

43 Gaceta de Buenos Aires- y Gaceta Ministerial- (1810-1813), reimpresión facsimilar, Junta de Historia y Numismática (dir.), Buenos Aires, Compañía Sudamericana de billetes de banco, 1911 (Tomo III). Las intervenciones de Monteagudo como redactor en la Gaceta de los viernes comienzan el 13 diciembre de 1811 y finalizan el 20 de marzo de 1812.

44 Ibídem: 71.

45 Ibídem: 81.

46 La Sociedad Patriótica y Literaria era una asociación que agrupaba a morenistas y, también, miembros de la Logia Lautaro (organización secreta liderada por José de San Martín y Carlos María de Alvear, en la cual se había iniciado Monteagudo, cuyo objetivo era el logro de la independencia y la creación de repúblicas en las colonias americanas). Creada por primera vez el 21 de marzo de 1811, fue el resultado de las reuniones en el Café de Marco. Su primera etapa fue efímera ya que culminó con la revolución del 5 y 6 de abril de 1811 que implicó el desplazamiento de los revolucionarios radicales del gobierno. La Sociedad fue refundada el 13 de enero de 1812, siendo Monteagudo su secretario hasta el mes de diciembre ya que luego ocuparía su presidencia.

47 Oración inaugural pronunciada en la apertura de la Sociedad Patriótica la tarde del 13 de enero de 1812. Año tercero de la libertad de la America del Sud por el ciudadano Don José Bernardo de Monteagudo, Imprenta de Niños Expósitos, Buenos Aires, p. 4. Disponible en la Biblioteca Digital Trapalanda de la Biblioteca Nacional Mariano Moreno. bastó que los españoles enarbolasen el estandarte de la cruz para usurpar los derechos de los hombres haciéndoles creer que «debían mirar como un don del cielo las cadenas que arrastraban ${ }^{48}$

La crítica al despotismo y al fanatismo se acompaña de una firme defensa de los imprescriptibles derechos del hombre. Derechos que el pueblo debe conocer puesto que el despotismo, se afirma, se cimenta en la ignorancia. De allí la tarea pedagógica que se proponen los revolucionarios de educar, aunque no sin prudencia, al pueblo.

Es en su diario Mártir o libre donde cuestiona, nuevamente, la influencia teocrática sobre la sociedad. ${ }^{49}$ En el ejemplar del lunes 11 de mayo de 1812 reflexiona sobre la obediencia que le debe el hombre a las sabias y justas leyes. Monteagudo clasifica las leyes en naturales, religiosas y civiles. Mientras se ocupa elogiosamente de las leyes naturales y civiles confiesa no querer detenerse en el análisis de las leyes religiosas debido a que "sería revolver la historia de todas las pasiones, extravagancias y absurdos de que ha sido capaz la ignorancia y la debilidad del hombre $»{ }^{50}$ Es que, reitera el redactor, «no hay delirio, ni maldad o capricho que no hayan osado autorizar en nombre de Dios la barbarie de los pueblos, la superchería de los ministros del culto y el interés de los déspotas $"{ }^{51}$ Aunque, advierte, la suya no es una crítica a la religión. Se trata, pues, de distinguir la religión de la política en un intento por poner fin a la tiranía que aterroriza al pueblo con "las amenazas del espionage político, y aún del religioso».52 Pues, como afirma Carozzi, "[la religión] no está, como en el antiguo iusnaturalismo católico, necesariamente involucrada en las cuestiones de la convivencia en la Ciudad terrena». ${ }^{53}$

No debe sorprendernos, entonces, que mientras que en las Cortes de Cádiz se debatía sobre el futuro de la Inquisición, Monteagudo se interesara en iniciar el debate en estas tierras desde las páginas de su periódico Mártir o libre. El ejemplar que aquí nos interesa es el número 8 correspondiente al lunes 18 de mayo de 1812. Pues en él se discute un tema que no muchos se proponían discutir: la abolición de la Inquisición. Recordemos que la censura pesaba, aún, en materia religiosa. En aquél ejemplar, leemos:

El silencio misterioso que han guardado hasta hoy nuestros más intrépidos escritores sobre el tribunal de la inquisición sin embargo de ser incompatible su permanencia con la ruina de la arbitrariedad; es un forzoso homenaje tributado a las preocupaciones públicas, que se adquieren en la escuela de la servidumbre, y que al fin es preciso atropellar cuando ha llegado la hora de combatir el crimen, y derribar de un solo golpe a los que profanaban el trono y el altar. $^{54}$

\section{Ibídem: 8.}

49 Mártir o libre, reimpresión facsimilar, Museo Mitre (dir.), Buenos Aires, 1910. Se trata de una publicación de corta vida dirigida por B. Monteagudo. Sólo se editaron nueve números desde el 29 de marzo al 25 de mayo de 1812. Como se sabe, la publicación criticaba duramente la política del Primer Triunvirato, a la que se acusaba de moderada, al tiempo que exaltaba las propuestas políticas de la Sociedad Patriótica.

50 Ibídem: 54.

51 Ídem.

52 Ibídem: 55.

53 Carozzi 2011: 251.

54 Mártir o libre: 57. 
Plantea así que la Inquisición sólo es compatible con la arbitrariedad. El hecho de que escriba que la arbitrariedad se encuentra en ruinas, evidencia su asociación con la Monarquía Hispánica. Ahora bien, en el periódico Monteagudo no se dedica a ofrecer sus propios argumentos sobre el asunto sino que le cuenta al lector: "Entre los periódicos de Cádiz se encuentran las siguientes reflexiones, que me ha parecido oportuno publicar con preferencia a las mías». ${ }^{55}$

Quizás Monteagudo haya preferido proceder de este modo como una medida de precaución ante la posibilidad de que sus opiniones fueran criticadas, pues más adelante aclara: "...que conozcan nuestros enemigos, que no es lo mismo atacar el culto que destruir sus abusos...». ${ }^{56}$

Monteagudo transcribe entonces una nota de un periódico de Cádiz titulada «¿Habrá inquisición, o no habrá inquisición?». Si bien no se aclara de qué periódico procede el fragmento, hemos podido rastrear que pertenece al periódico El Duende político número 4, publicado hacia fines de 1811 en Cádiz por la imprenta de Don Manuel Santiago de Quintana. ${ }^{57}$ Curiosamente uno de los editores y redactores del periódico fue el clérigo Miguel Cabral de Noroña, quien fuera procesado por la Inquisición en el año 1806 por haber pronunciado un sermón con fuerte contenido anticolonial. ${ }^{58}$

La transcripción de la nota, a pesar de ser incompleta, es fiel a la original. No se trata de una noticia convencional sino que la narración adopta la forma de la literatura sarcástica, una suerte de cuento en el que dos personajes ficticios entablan un diálogo. Los dos protagonistas son un Duende y un Literato, quienes discuten sobre la permanencia o la abolición de la Inquisición. El juego de nombres no es casual, la palabra "duende" designaba en la época, a modo de burla, a los curas mientras que la palabra "literato" hacía referencia a un personaje de las letras, del mundo de la filosofía. El diálogo entre estos dos personajes buscaba replicar el debate desarrollado en el recinto de las Cortes de Cádiz entre los diputados "serviles" y los liberales.

El Duende, luego de leer una Apología del Santo Oficio, que encuentra al pasar por una librería, no duda en defender al tribunal como condición necesaria para la existencia de la libertad de España. Sin embargo, el Literato afirma que es, en verdad, la Inquisición la que ha conducido a España a la opresión y al atraso. Así declara: «Es justo decir que la inquisición, con esas periódicas prohibiciones de libros ha sido una de las causas del atrazo en que se ven las ciencias y las artes en España, y también es justo añadir que se opone a la ilustración del pueblo». ${ }^{59}$

Es evidente aquí que la crítica al tribunal se debe a su persecución de los delitos ideológicos. Es por eso que el Literato no duda en afirmar que «libertad política de prensa e inquisición son tan opuestas como el día y la noche». ${ }^{60}$

\footnotetext{
55 Ídem.

56 Ídem.

58 Véase Soriano Muñoz 2013.

59 Mártir o libre: 62.

Ibídem: 63.
}

57 El Duende político, $\mathrm{N}^{\circ} 4,1811$, Cádiz, Imprenta de Don Manue Santiago de Quintana. Consultado en Hemeroteca digital Memoria de Madrid.
La Inquisición, se afirma, al impedir la libertad de pensamiento y expresión vulnera «los imprescriptibles derechos del hombre». ${ }^{61}$ Así, el Literato se pregunta:

Persiganse en buena hora los enemigos de J.C. pero ¿A qué viene ese secreto en todos los trámites de la causa que se les forma, esa absoluta incomunicación en que se les mantiene y ese silencio que ni aun permite decir que están presos? La justicia separa de la sociedad la persona del delincuente; pero dexa que permanezcan sus relaciones, mas la inquisición le arranca enteramente del mundo, le hace desaparecer.... ¿No será un recurso utilísimo para un tirano, y un instrumento para las maquinaciones del despotismo? ${ }^{62}$

La asociación se complejiza: la Inquisición se representa como un instrumento del despotismo y como tal ha de abolirse. Pero, es interesante señalar el modo en que el ataque al Santo Oficio no implica la lucha por la tolerancia religiosa. En la transcripción que Monteagudo hace del artículo es el Literato quien tiene la última palabra proclamando la incompatibilidad de la Inquisición con la libertad política de prensa. Ahora bien, al finalizar la transcripción del artículo, Monteagudo interpela al lector arengando a favor de la lucha por la libertad. Si bien nuestro editor comparte la oposición de los liberales gaditanos contra la Inquisición, no duda en distanciarse de ellos. Así concluye:

Entre nosotros está la LIBERTAD, y para poseerla no es preciso mas que unir nuestros esfuerzos: hagamos ver que somos dignos de ella, ya que los españoles de Cádiz aún nos conceptuan por bestias e incapaces de salir de la esclavitud, como lo sostenía pocos meses ha el togado Valiente atreviéndose a decir, que aun no sabia á que clase de animales pertenecían los americanos. ${ }^{63}$

Monteagudo realizaba pues un llamado a continuar la revolución y a que se considere el problema de la Inquisición. De este modo, la publicación del ejemplar demuestra la difusión de ideas y escritos sobre la Inquisición española entre la Península y América. A ambos lados del Atlántico se buscaba convertir al Santo Oficio en objeto de preocupación pública. Pero la preocupación de Monteagudo al respecto es singular pues nos muestra cómo, en tanto revolucionario exaltado, convierte a la Inquisición en un símbolo de la tiranía de la metrópolis.

Si bien sus reflexiones a propósito del tribunal se forjan, en su inicio, al calor de los debates peninsulares es interesante advertir que el revolucionario presta especial atención al contexto americano. Así, en el diario El Grito del Sud se evoca, nuevamente, al tribunal inquisitorial como un instrumento de la tiranía que busca encadenar el pensamiento. ${ }^{64}$ Recordemos que a través de sus páginas se buscaba disputar la conducción de la revolución y definir los temas de la agenda política bajo la clave de la libertad, tanto en las formas de la independencia, la supresión de la esclavitud o de la libertad de expresión. Y allí Monteagudo no duda en

\footnotetext{
61 Ibídem: 61.

62 Ibídem: 60

63 Ibídem: 64
}

64 El Grito del Sud, Tomo Primero, Año 1812, Buenos Aires, Imprenta de Niños Expósitos. Colección disponible en la Biblioteca Digital Trapalanda de la Biblioteca Nacional Mariano Moreno. El periódico, fundado por Monteagudo, se constituyó en el espacio de difusión de los ideales morenistas de la Sociedad Patriótica. 
afirmar que es la desconfianza del gobierno hacia el pueblo la que motivó la creación de los censores e inquisidores. ${ }^{65} \mathrm{En}$ ese sentido, se denuncia la actuación de la católica España: "A la verdad apenas se puede sufrir que un español desconfíe de nuestra adhesión al cristianismo...Ninguna nación del orbe se ha jactado más católica que la española y ninguna ha tenido menos fondo de piedad que ella....". ${ }^{66}$

Argumentando en una línea de reflexión similar a la de Las Casas y Raynal, afirma que los conquistadores españoles se han comportado como verdaderos antropófagos, pues con su arribo «millares de hombres son degollados, ó quemados vivos sin mas delito que ser hombres, y hombres mas inocentes, mas laboriosos, y de mas ingenio que sus fieros conquistadores». ${ }^{67}$ De este modo, España, «juzgándose destinada por el Cielo para acabar con la infidelidad, cree estarlo igualmente para acabar con los hombres». ${ }^{68}$

La crítica a la Monarquía Católica comprende también una crítica a la religión que enarbola pues, se afirma, no se trata de una "santa y sabia religión" ya que los españoles la han profanado. ${ }^{69}$ Se denuncia, así, la complicidad de las instituciones eclesiásticas españolas en la dominación colonial. En este contexto, se menciona a la Inquisición como instrumento de espionaje político-religioso. En el pliego del 12 de enero de 1813 se transcriben noticias acerca de los intentos revolucionarios que estallan intempestivamente en la Ciudad de los Reyes. Es entonces cuando el redactor afirma que "a pesar del espionaje, de las cárceles, y suplicios, no faltan en la antigua capital del Perú genios amantes de su patria». ${ }^{70}$ Es que la noticia cuenta que no pocos reos han sido llevados a las cárceles de la Inquisición aun cuando se señala que se ha publicado por un bando «la abolición de estas mansiones del dolor y del tormento». ${ }^{71}$ Posiblemente el autor del comunicado se refiere a los intentos de Virrey Abascal de rechazar el uso de la Inquisición como instrumento de represión de la disidencia con el fin de evitar la propaganda revolucionaria contra su gobierno. ${ }^{72}$ Lo cierto

\section{Ibídem: 18.}

66 Ibídem: 125.

67 Ibídem: 154-155.

68 Ibídem: 154.

69 De hecho, el propio redactor se burla de la supuesta "limpieza de sangre" que se atribuyen los conquistadores. Véase Ibídem: 128.

70 Ibídem: 205.

71 Ibídem: 206.

72 Peralta Ruiz advierte que Abascal mantuvo apartada a la Inquisición de su estrategia política fidelista y recibirá con buen agrado el decreto gaditano de abolición del tribunal. Sin embargo, no deja de ser simbólicamente interesante que el Virrey decidiera utilizar las instalaciones de la extinguida Inquisición para albergar en las cárceles secretas, las oficinas del secuestro, la contaduría y la saleta, a los rebeldes capturados en el Alto Perú y Chile, mientras que transformó a la sala de Audiencia y un dormitorio anexo en el cuartel de la guarnición virreinal. En 1815, ante la orden de restitución del tribunal, Abascal, a diferencia de lo ocurrido en Nueva España, fue reticente a su re-instalación. Será con la llegada del Virrey Joaquín de la Pezuela cuando la actuación del tribunal se normaliza persiguiendo a quienes habían celebrado su supresión alojándose en sus cárceles a presos políticos. Véase: Peralta Ruiz 2002: 79-103. No sorprende entonces, que en el Manifiesto que hace a las naciones el Congreso General Constituyente de las Provincias Unidas del Río de la Plata, sobre el tratamiento y crueldades que han sufrido de los españoles, y motivado la Declaración de su Independencia (25 de octubre de 1817) se afirme que los realistas «establecieron un sistema inquisitorial para todos estos castigos: han arrebatado vecinos sosegados, llevándolos a la otra parte de los es que la abolición del tribunal en Lima se producirá tiempo más tarde, aunque no de modo definitivo, tras la recepción del decreto de las Cortes de Cádiz, el 17 de julio de 1813.

La crítica a la Inquisición reaparece en otro ejemplar del El Grito del sud y a través de la pluma de otro comunicado en el que se afirma:

¿Qué os parece americanos? Aun el mismo tribunal depositario y defensa de la fe, la negra inquisición traidora a su confianza, y desviándose de sus deberes nos persiguen, y declarándonos traidores infieles y hereges nos carga de censuras y ordenan queden insepultos nuestros cadáveres sin mas motivo que tomar las armas en defensa de la libertad, y de nuestra patria. El punto se ha hecho de religión. ${ }^{73}$

Pero así como hay eclesiásticos realistas, no se deja de reconocer que también los hay revolucionarios. No sorprende entonces que en ocasión de comentarse la revolución de independencia de Cartagena, apelando a las noticias extraídas de El Español de B. White, se repare en la decisión de los revolucionarios de suprimir la Inquisición cuando su abolición era aún objeto de discusión en las Cortes de Cádiz. Al respecto, el redactor de El Grito del Sud escribe: «El pueblo también pidió que se extinguiese la inquisición, cuya justa solicitud fue atendida, y en consecuencia no existe ya un tribunal eregido por los reyes para servir de apoyo a su tiranía». ${ }^{74}$

La crítica al tribunal inquisitorial permitía denunciar la ofensa a los imprescriptibles derechos del hombre que, en nombre de la religión, practicaba la metrópolis. Y desconocer a la Monarquía Católica implicaba, a la vez, desconocer la legitimidad divina de los reyes. La crítica a la Inquisición encierra así una reflexión sobre el origen mismo de la soberanía. El origen divino de los reyes se cuestiona argumentando: "Los autores de tan sacrílega opinión, semejantes a los gigantes de la fabula, quisieran escalar los Cielos, y destronar al Omnipotente, para que los omnipotentes de la tierra, no tengan en aquél un rival, que parta con estos las adoraciones y los cultos». ${ }^{75}$

Por cierto, lo interesante es que los revolucionarios no apelan al poder del Omnipotente para limitar el poder de quienes gobiernan la ciudad de los hombres. Por el contrario, enaltecen la voluntad de los hombres en la creación de su propio orden político. Se apuesta así a distinguir y separar la esfera religiosa de la política para reinventar las bases del poder temporal. Se trata de la construcción de un nuevo origen que, apelando a los derechos del hombre, logra construir una distancia crítica entre gobernantes y gobernados. La búsqueda de un nuevo absoluto que reemplace a la legitimidad divina se encontrará en la proclamación de la soberanía popular. Así, podemos leer:

Mas si queremos buscar la verdad con sinceridad, abramos el gran libro de los derechos del hombre, y en él leeremos, que todos los hombres son iguales por naturaleza, que todos nacen con unos mismos derechos y que necesitados a reunirse en sociedad, debieron elegir una persona física, ó moral, a quien ellos cediesen aquellas facultades, que creyesen necesarias para el fin de su asociación... ${ }^{76}$

mares, para ser juzgados por delitos supuestos, y han conducido al suplicio, sin proceso, a una gran multitud de Ciudadanos».

73 El Grito del Sud: 219.

74 Ibídem: 152.

75 Ibídem: 202.

76 Ídem. 
Son los hombres quienes se dan a sí mismos un gobierno. A Dios se lo representa ahora como el testigo del acto de la asociación y no ya como el fundador del nuevo orden. ${ }^{77}$ Aun cuando la suya se imagina también como una causa sagrada. ${ }^{78}$ El gobierno debe, pues, constituirse en defensor de esos derechos. Y para ello, se afirma, no basta con independizarse de España, es preciso evitar el surgimiento de despotismos interiores conformando un gobierno liberal. Es por eso que se apuesta a la pedagogía cívica y a la elaboración de una constitución que garantice los derechos. No sorprende entonces que desde las páginas del periódico se impulse la reunión de una asamblea constituyente, con representantes de todos los pueblos del ex-virreinato, capaz de definir el nuevo rumbo político de la región. Tras el movimiento revolucionario de octubre de 1812, en el que Monteagudo participó activamente, se pone fin al Primer Triunvirato creándose uno nuevo que resolverá convocar a un congreso.

Tiempo más tarde, la Asamblea del Año XIII, bajo la hegemonía de la facción morenista e impulsada por la Logia Lautaro, decreta la abolición de la Inquisición, apenas un mes después que las Cortes de Cádiz. ${ }^{79}$ Encontramos a Monteagudo participando de la experiencia asamblearia en calidad de diputado por Mendoza y prestando su pluma en $E l$ Redactor de la Asamblea, papel que debía hacer públicas las acciones de los diputados. No es casual que sea esta asamblea, que omite el juramento de fidelidad a Fernando VII y cuyos diputados juran por la nación, la que decrete la abolición de la Inquisición. Se trata de un congreso que intenta salir del depósito de la soberanía en nombre de Fernando VII en vistas a la creación de un nuevo orden político. Como se sabe, la definición del nuevo sujeto de imputación soberana no llegará hasta la declaración de la Independencia. No obstante, mientras tanto el Congreso de 1813 avanza sobre cuestiones que considera claves, y entre ellas se encuentra la abolición del tribunal y, unido a éste, la supresión de los instrumentos de tortura. La sesión del miércoles 24 de marzo de 1813 declara así abolida la Inquisición en todos los pueblos del territorio de las Provincias Unidas del Río de la Plata a instancias de una moción presentada por el diputado de Salta Pedro José Agrelo. ${ }^{80}$ Pero, es importante recordar que la abolición definitiva de la Inquisición de Lima se produce con la entrada del General San Martín a la Ciudad de los Reyes (1821). Y en ese escenario veremos reaparecer las iniciativas de Monteagudo, devenido en ministro del Protectorado. ${ }^{81}$

77 Sobre la cuestión del pactum subiectionis en la filosofía política véase Carozzi 2011: 280-281.

78 Por cierto, la apelación a Dios es mayor en el momento en que se reflexiona sobre los avatares de la guerra, véase Ortemberg 2011-2012.

79 Las medidas eclesiásticas de la Asamblea estuvieron influenciadas por las tendencias galicanas y tardo-jansenistas presentes en el clero criollo. Véase: Di Stefano y Martínez 2011 y Ternavasio 2013.

80 El Redactor de la Asamblea, N5, 27-3-1813 (sesión del miércoles 24 de marzo). Reproducción facsimilar en: Junta de Historia y Numismática americana, Buenos Aires, 1913, p.18. La abolición de la Inquisición supuso la restitución de la vigilancia en cuestiones de fe a los tribunales eclesiásticos.

81 En Lima las acciones de San Martín y su ministro Monteagudo resultaron claves en el desmantelamiento simbólico de la extinta Inquisición. El ministro propuso cambiar el nombre de la Plaza de la Inquisición por el de Plaza de la Constitución y mediante un decreto el antiguo local de la Inquisición se convertiría, por un tiempo, en
Poco tiempo después de abolida la Inquisición, al momento de instituirse las fiestas mayas, se proclama: «Es un deber de los hombres libres inmortalizar el día del nacimiento de la patria, y recordar al pueblo venidero el feliz momento en que el brazo de los más intrépidos quebró el ídolo y derribó el altar de la tiranía». ${ }^{82}$ La lucha contra la tiranía aparece asociada a la lucha contra el fanatismo. Así elige recordarlo Ignacio Núñez en sus Noticias Históricas ${ }^{83}$ : «era propósito de la Revolución de Mayo establecer leyes que protegiesen los derechos de hombres libres en lugar de leyes de Indias que los anatemizasen, tolerancia en lugar de inquisición». ${ }^{84}$

No obstante también aquí, como en la Península, la abolición de la Inquisición no implicaba libertad religiosa. Como advierte N. Botana, mientras que en la Constitución de Cádiz se prohíbe el ejercicio de cualquier religión que no sea la católica, en el Proyecto de Constitución para la Provincias Unidas del Río de la Plata (elaborado en 1812 pero dado a conocer en 1813) se declara al dogma católico como la religión del Estado pero sin prohibirse el ejercicio de otra religión. ${ }^{85}$ La tolerancia en materia religiosa tardará en legislarse y convertirse en realidad..$^{86}$ Lo cierto es que, como señala Di Stefano,

la revolución despoja a la soberanía de sus connotaciones religiosas e introduce en consecuencia una distinción -cuyas vastas derivaciones no se advierten de inmediatoentre la figura del ciudadano y la del feligrés, a la vez que se crean nuevos espacios, prácticas e instituciones que se suponen ajenos a la autoridad religiosa. ${ }^{87}$

De este modo, mientras que la Península decreta la abolición de la Inquisición en febrero de 1813, noticia que se da a conocer en Lima recién el 30 de julio, la Asamblea del año XIII, indudablemente conocedora, como lo demuestra Monteagudo, de los debates producidos en Cádiz pero también de los antecedentes americanos, decide suprimirla en marzo de ese mismo año. Así, no sorprende que un artículo publicado en La Gaceta de Buenos Aires del día 21 de julio de 1813, cuando recién se conocía en América el decreto de abolición peninsular, se enorgulleciera del accionar de la Asamblea y se lamentara de los arduos debates generados en Cádiz para la consecución del mismo objetivo. En esos tiempos La Gaceta se encontraba bajo la dirección

el recinto de la Alta Cámara de Justicia. Haciendo uso de esa misma dimensión simbólica, tras el asesinato de Monteagudo, sus opositores políticos hicieron circular un epitafio anónimo en el que se lo acusaba de "honorable inquisidor de Estado".

82 El Redactor de la Asamblea, N 8, 8-5-1813 (sesión del miércoles 5 de mayo). Reproducción facsimilar en: Junta de Historia y Numismática americana (dir.), Buenos Aires, 1913, p. 30.

83 Ignacio Núñez (1792-1846) fue un patriota y hombre de letras que hacia 1825 publicó, posiblemente por encargo oficial, el texto titulado Noticias históricas, políticas y estadísticas de las Provincias Unidas del Río de la Plata. Texto cuyo objetivo era informar a los políticos europeos sobre los asuntos del Río de la Plata. En 1844 escribió Noticias históricas de la República Argentina. Sus escritos fueron luego recopilados y ampliados por su hijo quien los publicó en el año 1857.

84 Núñez, I. 1898. Noticias históricas de la República Argentina, Obra póstuma, Segunda Edición aumentada y corregida por el hijo del autor Sr. Don Julio Núñez: 266. Buenos Aires: Litografía, Imprenta y Encuadernación de Guillermo Kraft.

85 Botana 2007.

86 Véase Calvo 2004.

87 Di Stefano, R. 2010: 124. 
de Monteagudo. Así, quien por entonces era su redactor, afirmaba:

Las dificultades que ha tenido que vencer el partido, que se dice liberal, de las Cortes españolas, y los debates peligrosos que ha sostenido para alcanzar la abolición del Tribunal del Santo Oficio, es una demostración muy clara del grado de ceguera y estupidez, a que reduce a los Pueblos un mal gobierno. ${ }^{88}$

\section{LA CRÍTICA AL GOBIERNO INQUISITORIAL}

Tras la restauración de Fernando VII al trono, en el contexto político de la Santa Alianza, el tribunal inquisitorial es restituido en España. Por ese entonces, ante los temores acerca del destino de las armas revolucionarias, algunos de los diputados de la Asamblea Constituyente, entre los que se encontraba Monteagudo, proponen aplazar la sanción de una constitución y apostar a la formación de un ejecutivo fuerte que concentre el poder. En 1814 la Asamblea decidirá la creación de un nuevo poder ejecutivo unipersonal, el Director Supremo. Pero las tensiones políticas no dejarán de agudizarse al calor de las disputas entre federalistas y centralistas. Mientras tanto, aumenta el número de publicaciones periódicas, al haberse creado desde 1815 nuevas imprentas. Se trata de publicaciones que comienzan a debatir abiertamente sobre las formas de gobierno que podrían adoptarse una vez lograda la independencia.

En ese efervescente escenario nuestros políticos y publicistas seguirán atentos el devenir de la Inquisición en el resto de América y en la Península, tal como se evidencia en algunos artículos de la Gaceta de Buenos Aires en tiempos en que Monteagudo era su editor. También el periódico El Independiente, entre cuyos redactores probablemente se encontraba el revolucionario tucumano, prestará atención a la problemática. Así, en el ejemplar número 5 se reproduce una noticia publicada en el Correo Brasilense sobre el decreto de la restauración del tribunal, en la que se afirma: "Este singular documento representa muy al natural al Piloto remando contra la mar, y es tan fuera de propósito, que puede decirse que trahe consigo su misma refutación». ${ }^{89}$

En este escenario, Fr. Camilo Henríquez tampoco dudará en conjugar la lucha revolucionaria con la oposición al Santo Oficio..$^{90}$ Recordemos que Henríquez había nacido hacia 1769 en Valdivia, ciudad que dependía del Virreinato del Perú, pero realizó su formación en el Colegio Carolino de la ciudad de Santiago de Chile. A la edad de 15 años viajó a Lima para iniciarse en la vida religiosa. Allí, hacia 1787, se ordenó en la comunidad de los Frailes de la Buena Muerte. Fue este religioso quien, a diferencia de Monteagudo, sufrió la censura inquisitorial de un modo directo en su vida. En tres ocasiones fue denunciado ante la Inquisición de Lima: la primera en 1796 por "proposiciones heréticas" y otras dos veces, en 1802 y 1809, por tener libros prohibidos

88 Gaceta de Buenos Aires- y Gaceta Ministerial: 405.

89 El Independiente, $\mathrm{N}^{\circ} 5,7-2-1815$, p. 70. Ejemplar disponible en la Biblioteca Digital Trapalanda de la Biblioteca Nacional Mariano Moreno.

90 Sobre el itinerario político e intelectual de Fr. Henríquez véase Amunátegui 1889 y Píriz García de la Huerta 2012. y dedicarse a la lectura de los filósofos franceses. Como recuerda R. Palma en sus Anales de la Inquisición de Lima, hacia 1809,

Un inquisidor se constituyó en su celda, y después de registrar los estantes y muebles se retiró sin encontrar obra digna de censura. Henríquez se juzgaba ya libre; pero el denunciante insistió y la Inquisición dispuso una nueva pesquisa. En ella se encontró que los colchones de la cama de Henríquez estaban llenos de libros y el ilustrado chileno fue en el acto conducido a las mazmorras del Santo Oficio. $^{91}$

Un contemporáneo suyo, Fr. Melchor Martínez, constataba: «Por haber sido declaradamente secuaz de Voltaire, Rousseau y otros herejes de esta clase había sido castigado por la Inquisición de Lima».92 Lo cierto es que tras la denuncia debió migrar a Quito, aunque no se sabe si fue por mandato del Santo Oficio o de su propia Orden. Allí será testigo del movimiento juntista que destituyó al virrey en 1809 y de la represión de los realistas en los episodios de la matanza del 2 de agosto de 1810. Y es aquí cuando comienza su compromiso con la causa revolucionaria.

Así, tras conocer la noticia de la formación de la Junta de gobierno en Santiago de Chile, no dudará en trasladarse a la ciudad trasandina. Pronto se iniciará en la vida política con la Proclama de Quirino Lemáchez, seudónimo del autor, donde convoca a la elección de diputados para el Congreso Nacional capaces de luchar por la independencia. Interesante es que en ella el fraile legitimaba sus ideas afirmando:

¿Recibió alguno patentes del cielo que acrediten que debe mandaros? La naturaleza nos hizo iguales, y solamente en fuerza de un pacto libre, espontánea y voluntariamente celebrado, puede otro hombre ejercer sobre nosotros una autoridad justa, legítima y razonable. ${ }^{93}$

En el marco de la inauguración del Congreso, en el que fue elegido como diputado suplente, pronunciará un sermón que, aunque de contenido más moderado, intenta demostrar que la doctrina católica no está en contradicción con la política. Es importante advertir que aquél Congreso dispuso el 25 de septiembre de 1811 retener la renta de la Canonjía de la Catedral destinada al financiamiento del Santo Oficio para dedicarlo a otro fin piadoso. Al respecto, el receptor de cuentas de la comisaría de Santiago, quien se había opuesto a la medida, le escribía al Consejo de la Inquisición:

...las autoridades y doctrinas que expongo están en oposición con las máximas y opiniones políticas del día; pero me quedará la satisfacción de haber propugnado en esto la causa de la religión, unida con la del Santo Oficio, contra la cual se divisa ya desarrollarse en papeles públicos la simiente de las convulsiones civiles de estos países. ${ }^{94}$

Y, precisamente, la participación más significativa del fraile la encontramos en la prensa. En enero de 1812 la Junta de Gobierno, a pedido de José Miguel Carreras, lo nombra redactor del semanario La aurora de Chile. Allí

\footnotetext{
91 Palma 1863.

92 Edwards 1934: 7.

93 Silva Castro 1960: 46.

94 Toribio Medina 1952: 663-664.
} 
se dedicará a difundir el ideario revolucionario. $Y$ entre sus páginas encontramos ya menciones al problema de la Inquisición. ${ }^{95}$ Sin embargo, el semanario sufre la censura en agosto de 1812. Pero no por ello el fraile dejará de colaborar con el gobierno de Carrera. De hecho, lo encontramos participando en la redacción del Reglamento Constitucional Provisorio de 1812 y en el Senado. Pocos días después de que se publique el último número de La Aurora de Chile, el 6 de abril de 1813 Henríquez comienza la publicación de El Monitor Araucano. Entre sus páginas también se pueden leer reflexiones a propósito del Santo Oficio. ${ }^{96}$ En el contexto de rivalidades entre Carrera y O'Higgins, se mostró siempre en apoyo del primero. Pero, a diferencia de Monteagudo, el fraile no usaba más que las armas de papel.

Tras la derrota de los ejércitos patrióticos en Rancagua en octubre de 1814, se autoexilia en el Río de la Plata donde seguirá difundiendo las ideas liberales. Diego Antonio Barros, quien era por entonces regidor del Cabildo de Buenos Aires, es quien lo inserta en la esfera pública porteña recomendándolo como redactor. Aunque su precaria situación económica lo impulsa a ejercer, también, el oficio de médico.

Al momento de su arribo, la situación en Buenos Aires no era promisoria. El avance de las tropas realistas, la sublevación de la Banda Oriental y las provincias del Litoral amenazaban al poder revolucionario. El gobierno del Director Supremo Alvear se hallaba en crisis. Hacia abril de 1815 una revolución armada provocó su caída y el fin de la Asamblea del año XIII. Un nuevo gobierno y Estatuto provisorio se formaban para solucionar la situación de acefalía y se resolvía convocar a un nuevo congreso constituyente. En el marco de la crisis política el tono de la opinión pública se agudizaba. Por su parte, Monteagudo, tan comprometido con el gobierno de Alvear, sufre un juicio político que lo condena al destierro. Pero el abogado tucumano logra escapar del barco en que se hallaba preso e inicia así su exilio durante los años 1815 a 1817. El revolucionario inició un variado itinerario, recalando en Río de Janeiro, Londres y Francia. El exilio constituye, como señala F. Herrero, una nueva etapa de su formación.

Por ese entonces, en mayo de 1815, Camilo Henríquez publicará en Buenos Aires unos escritos bajo el título Observaciones acerca de algunos asuntos útiles. ${ }^{97}$ En su primer número la crítica a la Inquisición se hace presente como un recurso para defender la libertad civil, especialmente la libertad de pensamiento. Si bien en este ejemplar no hay una reivindicación de la libertad religiosa, el autor abunda en las críticas al fanatismo y no duda en hacer suyas las reflexiones del poeta inglés Milton a propósito de la libertad. Habiendo, pues, caracterizado al gobierno de España

95 Véase, entre otros: La Aurora de Chile N¹3 (7-5-1812), N¹5 (21-5-1812) y N¹7 (4-6-1812). Disponibles en: www.auroradechile.cl

96 Véase, entre otros: El Monitor Araucano N41 (10-7-1813), $N^{\circ} 48$ (27-7-1813), Nº1 (9-11-1813) y N 53 (17-6-1814). Disponibles en: Biblioteca digital Memoria chilena de la Biblioteca Nacional de Chile.

97 Se trata de una suerte de periódico mensual que consta de 4 números con un total de 36 páginas de numeración correlativa publicado tanto por la Imprenta Niños Expósitos como por la Imprenta de M. J. Gandarillas y Socios. como inquisitorial, sentencia: «atacar la libertad de pensamiento es la más bárbara de las tiranías». ${ }^{98}$

La crítica al "gobierno inquisitorial" de España se acompaña del elogio a los gobiernos liberales de Inglaterra y Estados Unidos. Es en el ejemplar número tres donde el fraile se dedica a reflexionar sobre Norteamérica, país que considera como la morada de los derechos del hombre. Refiriéndose a la historia de sus primeros colonos advierte: «Estos extranjeros eran hijos perdidos, abandonados de la madre patria, dichosos por haber nacido después de Colon, pues les descubrió un país donde el fanatismo no había perseguido a alguno". ${ }^{99}$ De modo que, afirma, aquél pueblo pudo aprender a aborrecer la tiranía y apreciar la doctrina de la tolerancia religiosa. Las ideas de Locke, Raynal, Rousseau y Montesquieu dialogan en su escrito. Escrito en el que la reivindicación de los Cuáqueros es, sin lugar a dudas, persistente. Así al interrogarse sobre el florecimiento norteamericano, llama al lector a la reflexión:

Permitase preguntar de paso si es compatible con este espíritu, con esta caridad universal el celo inquisitorial y sanguinario? Comparense los sentimientos de beneficencia de uno de los mayores hombres del mundo con el espíritu feroz de los que quieren que las opiniones teológicas se sostengan con las bayonetas. Comparense la prosperidad, la fuerza, el esplendor, la dicha de los Estados Unidos y de todos los pueblos tolerantes, con la miseria, la debilidad, la obscuridad, las calamidades de las naciones intolerantes, estúpidas y feroces. ${ }^{100}$

Luego de formular este interrogante, Henríquez desarrolla en una nota a pie de página un elogioso comentario a la disertación a propósito de la Inquisición de Antonio José Ruiz de Padrón, quien fuera Ministro calificado del Santo Oficio, Abad de Villa Martin y Diputado en Cortes por Canarias. La disertación fue leída en público el 18 de enero de 1813 en las Cortes de Cádiz y Henríquez no duda en calificarla como «una de las obras más luminosas, sabias e interesantes que aparecieron en la revolución de España, y que sería muy de desear que reimprimiésemos en una suscripción». ${ }^{101}$

Retoma, pues, la caracterización de Ruiz de Padrón que define al Santo Oficio como un tribunal diabólico al servicio de los déspotas. ${ }^{102} \mathrm{Al}$ igual que el artículo que reproducía Monteagudo en Mártir o libre, se insiste en la violación de los derechos del hombre, en las atroces torturas y el aislamiento que sufrían sus víctimas. Luego de describir los tormentos inquisitoriales, Henríquez se pregunta: "Y con todo, se atreve alguno a llamar Santo a este tribunal? ${ }^{103}$

En su argumentación contrapone la Inquisición, considerada como un pilar del despotismo, con las recientes leyes proclamadas en América. Evoca, incluso, la emoción

98 Observaciones acerca de algunos asuntos útiles, Buenos Aires, Imprenta de Niños Expósitos/ Imprenta Gandarillas y Socios, 1815, p. 4. (Reproducción digital en Google books)

99 Ibídem: 22.

100 Ibídem: 25.

101 Ídem.

102 Remitimos al original: Dictamen del Doctor D. Antonio José Ruiz de Padrón, Ministro calificador del Santo Oficio, Abad de Villamartin de Valdeorres, y diputado en Cortés por las Islas Canarias, que se leyó en la Sesión Pública de 18 de Enero sobre el Tribunal de la Inquisición, Reimpreso en la Oficina de Don Antonio Rodríguez, Coruña, 1813. Disponible en el repositorio digital "Europeana Collections".

103 Observaciones acerca de algunos asuntos útiles: 26. 
del pueblo de Lima al enterarse de la noticia de la abolición del Santo Oficio decretada por las Cortes de Cádiz. Pues recordemos que cuando escribe sus reflexiones corría el año 1815 , año en que el tribunal inquisitorial ya había sido restaurado en la Península y las regiones fidelistas de Hispanoamérica. Es por eso que no duda en pronunciarse en contra del restablecimiento de la Inquisición al preguntarse: «No es este un atentado contra la patria, contra la naturaleza, contra los derechos del hombre y del ciudadano, contra las luces, contra la libertad?»104

Es que, de hecho, el recurso a la prisión inquisitorial seguía viviéndose como una amenaza por parte de quienes se aventuraban a la revolución. Asimismo, la Capitanía General de Chile continuaba enviando expedientes inquisitoriales y remesas de dinero a la Ciudad de los Reyes. ${ }^{105}$ La crítica a la política inquisitorial no era, pues, asunto del pasado. ${ }^{106}$

Pero el Santo Oficio no constituye, en su argumentación, un simple recurso para atacar a España. El hecho de que la crítica se acompañe del elogio al gobierno liberal de Estados Unidos nos advierte acerca de las nuevas formas en que se comienza a pensar la relación entre política y religión. Aun cuando ello no implique descartar a la religión como recurso del gobierno. De hecho, en el ejemplar siguiente, Henríquez analiza la utilidad política de la religión y de los religiosos. $Y$ es en ese sentido que pone como ejemplo la labor de los religiosos durante la defensa de Buenos Aires en el contexto de las invasiones inglesas. Pero al hacerlo es llamativo que resalte, una vez más, el valor de la tolerancia:

Entonces fue cuando dieron un brillante ejemplo [se refiere a los hospitales a cargo de los religiosos] de tolerancia, y de la beneficencia que no hace distinción entre los afligidos de todas las sectas. Fue singular el esmero con que curaron y asistieron a los Ingleses heridos. ${ }^{107}$

Es tal la importancia que el fraile le otorga a la diatriba contra la Inquisición que advierte: «Pero asunto de tanto interés y trascendencia, y que guía a tantos desenquilos, debe tratarse con más extensión y no contenerse en los límites de una nota». ${ }^{108}$

\section{Ibídem: 26.}

105 De hecho, el último de los procesados por el Santo Oficio que provenía de la región de Chile fue don José Antonio Espinosa, oficial de la alcaidía de la Aduana del Callao, quien fue denunciado en Lima en 1820 por haber leído las cartas de Abelardo y Eloísa. Véase Toribio Medina 1952: 659.

106 Es interesante señalar que Gabriel Lafond du Lucy evoca en sus memorias de viaje a Chile los episodios de las guerras de independencia comparando la administración de Osorio, especialmente su medida de instalación de tribunales de purificación para comprobar quiénes eran súbditos leales, con los métodos de la Inquisición. Así afirma: «No es posible imajinar nada tan cruelmente arbitrario como los procedimientos de este tribunal, que absolvía o condenaba a su antojo, sin sujeción a las leyes o preceptos establecidos. Las prisiones llenas de víctimas, los lugares de destierro cubiertos de proscritos, Chile jimiendo bajo la administración imprudente de Osorio, tales fueron los frutos de esta inquisición política». Véase Lafond du Lucy, G. 1911 [1853]. Viaje a Chile: 156. Santiago de Chile: Imprenta universitaria. Vale advertir también que es en el año 1816 cuando el Papa Pío VII prohíbe el uso de la tortura en todos los tribunales del Santo Oficio. Véase Prosperi (dir.) 2010, vol. 1: 241.

107 Observaciones acerca de algunos asuntos útiles: 33.

108 Observaciones acerca de algunos asuntos útiles: 26.
Al respecto, hemos rastreado que fragmentos de la disertación de Ruiz de Padrón circularon en El Censor, cuando su director era Antonio José Valdés. La reproducción de las ideas del diputado canario, lejos de pasar desapercibidas, causaron polémica en la prensa. De hecho, el redactor de EI Censor afirmaba:

Habiendo leído con agrado la nota sobre el Dr. Ruiz de Padron, que trae en su número 3 el autor de las observaciones mensuales, y conociendo cuanto puede contribuir la circulación de semejantes ideas, en un pueblo que trata de sacudir sus preocupaciones y fomentarse, he preferido dar lugar en este número a un ligero extracto del inmortal discurso del Dr. Ruiz de Padron, con preferencia a varias apuntaciones que tengo hechas sobre diversos objetos, e iran saliendo, sucesivamente, asi como varios artículos que se me han comunicado, que acaso no agradaran a mas de cuatro. ${ }^{109}$

Difusión necesaria, afirma, cuando se ha restaurado precisamente en la Península la tiranía que ha sorprendido al propio Dr. Ruiz de Padrón "sepultado en un calabozo». ${ }^{110}$

Tiempo más tarde, La Prensa Argentina en su ejemplar número 1 afirmaba que deseaba la completa publicación del texto de Ruiz de Padrón para poder instruirse en el tema. ${ }^{111} \mathrm{El}$ editor no dudaba en llamar a Ruiz de Padrón pseudo-inquisidor, al haber éste desertado de la institución para lograr su abolición. La publicación de sus ideas encendió el debate acerca de la esencia benéfica o no del Santo Oficio y sobre la problemática cuestión de la censura. ${ }^{112}$

Curiosamente la crítica al Santo Oficio reaparecerá en otros escritos de Henríquez, esta vez de índole dramático. El teatro, al igual que la prensa, se consideraba una escuela pública destinada a educar a los ciudadanos. Henríquez, como tantos otros, afirmaba ya en el año 1812: "la musa dramática es grande instrumento en manos de la política». ${ }^{113}$ Esta misma concepción guiaba a quienes propiciaban el teatro en la ciudad porteña. En un artículo del periódico El independiente, cuyos editores, se estima, fueron Monteagudo o Manuel Moreno, se afirma: «el teatro vendrá a ser el libro donde se instruyan los ciudadanos». ${ }^{114}$

Allí, en las tablas porteñas, como afirma M. Bosch, la figura del inquisidor cobraba protagonismo pues, explica:

109 El Censor, Nº 3, 7-9-1815, p. 1. Ejemplar disponible en la Biblioteca Digital Trapalanda de la Biblioteca Nacional Mariano Moreno. Se trata del periódico oficial del Cabildo de Buenos Aires.

110 Ibídem: 2. Muchas son las reflexiones en torno a la Inquisición y el gobierno inquisitorial en el periódico. Véase: El Censor $n^{\circ} 1, n^{\circ} 6$ y $n^{\circ} 8$. No sorprende que allí se compare la revolución rioplatense con la revolución de Holanda, que supuso junto a la defensa del republicanismo una crítica al fanatismo religioso.

111 "La Prensa Argentina", reproducción facsimilar en Biblioteca de Mayo: colección de obras y documentos para la Historia Argentina, Vol. 7, Buenos Aires, Senado de la Nación, 1960-1963. Es importante recordar que el director del periódico era Antonio José Valdés, que también lo era por aquel tiempo en El Censor.

112 Por razones de espacio, no nos extendemos en esos debates. Véase: El Censor n³, 7-9-1815; La Prensa Argentina n¹, 12-9-1815, "Comunicado con carta al editor de La Prensa" en El Censor n ${ }^{\circ}$, 12-101815 y continúa en El Censor N9, 19-10-1815; La Prensa Argentina N7, 24-10-1815 y La Prensa Argentina N¹3, 5-12-1815.

113 La Aurora de Chile, N³1 (10-9-1812).

114 El Independiente, $\mathrm{N}^{\circ} 4,31-1-1815$. Ejemplar disponible en la Biblioteca Digital Trapalanda de la Biblioteca Nacional Mariano Moreno. 
«El teatro, decían los mismos cronistas, está destinado a presentar a la execración pública todos los crímenes y todos los grandes criminales, y uno de estos, y tal vez el más repelente, era el inquisidor». ${ }^{115}$ Ya en 1812 vemos representarse la obra El Triunfo de la naturaleza, una tragedia en cinco actos originalmente escrita en portugués por Vicente Pedro Nolasco de Acuña, que planteaba, en términos metafóricos, una crítica a la intolerancia y la represión inquisitorial. No pocos son los estudiosos del teatro que atribuyen la traducción de la obra a Monteagudo, cuyo texto se publicará hacia 1814. Más allá de las dudas acerca de la autoría de la traducción, lo cierto es que en el prólogo el editor justifica la publicación de la obra como un medio de educar al pueblo, cuya voluntad es imprescindible a la hora de transformar las leyes y lograr «una obediencia libre, gustosa y general». Así explica:

Esto es doblemente necesario en unos Países, donde no se ha permitido la menor ilustración, y donde con todo estudio se había propuesto el Gobierno mantener envueltos los Pueblos en las tinieblas de la ignorancia más estúpida, haciéndolos confundir desde su infancia las verdaderas máximas de la Religión y de la moral con el fanatismo, y superstición más degradante. ${ }^{116}$

Luego de recuperar las ideas de Jovellanos y White, el autor no duda en representar a América como la promesa de una nueva política. Promesa en la que también cifraba sus esperanzas el autor de la pieza teatral. Sin embargo, desde las jerarquías eclesiásticas, el porvenir se pensaba en clave de una peligrosa incertidumbre. Así lo hizo notar F. Isidoro Celestino Guerra en el Sermón de Santo Domingo de Guzmán predicado en el día de su fiesta y difundido en la imprenta en el año 1815. Desde el púlpito cuestionaba la irreligión de los libertinos con las siguientes palabras:

Quando digo derramar públicamente el veneno, no hablo solo de lo que se dice, y hace en los estrados, y Cafes con escándalo de los que conservan aun algun trato de piedad, hablo principalmente de lo que se ha hecho con la mayor publicidad a vista, y paciencia de los Magistrados, y de un concurso tan distinguido como numeroso. Sin duda ya lo habréis comprendido, que hablo de la representación de esa Tragedia traducida aquí de la portuguesa a nuestra lengua, y dada por la prensa a la luz publica con el título de Triunfo de la naturaleza... Los teatros no son sino las escuelas del Demonio. ${ }^{117}$

Cuestiona el "escándalo monstruoso" de ver que aquellos que mandan, y que por tanto debieran creer más, son los que menos creen y quienes «son seducidos con más

\section{Bosch 1910.}

116 "El triunfo de la naturaleza, tragedia en cinco actos originalmente escrita en verso portugués por el Doctor Vicente Pedro Nolasco de Acuña, vertida en prosa castellana para el teatro de Buenos Aires. Imprenta de Niños Expósitos, Buenos Aires, 1814", en La Revolución de Mayo a través de los impresos de la época, Primera Serie, 18091815, Tomo VI, 1814-1815, BA: Comisión Nacional Ejecutiva del $150^{\circ}$ Aniversario de la Revolución de Mayo/AGN, 1967, p. 4.

117 "Sermón de Santo Domingo de Guzmán, predicado en el día de su fiesta por el M.R.P. M. Ex - Provincial F. Isidoro Celestino Guerra del Orden de Predicadores, Imprenta de Gandarillas y Socios, Buenos Aires, 1815", en La Revolución de Mayo a través de los impresos de la época, Primera Serie, 1809-1815, Tomo VI, 1814-1815, BA: Comisión Nacional Ejecutiva del $150^{\circ}$ Aniversario de la Revolución de Mayo/ AGN, 1967, p. 314 facilidad» por la filosofía libertina de Rousseau y Voltaire, "esos monstruos de los últimos tiempos». Preocupado por los asuntos de la conciencia de quien manda, propone que a través de la sanción de una ley se garantice que quien gobierna sea un verdadero católico. Cuestiona el atrevimiento de leer libros prohibidos

y esto sin mas titulo ni razón para ello, como lo he oído yo mismo, que haberse abolido civilmente el tribunal de la Inquisición: como si la potestad secular pudiese hacer licito con este hecho lo que la Iglesia con la autoridad divina, que recibió de Jesu-Cristo, prohíbe como malo, baxo la terrible pena de excomunión mayor. ${ }^{118}$

Aconseja pues no atreverse a saber más de lo que conviene saber. En ese entonces la cuestión acerca del control eclesiástico sobre los asuntos de la opinión pública produjo una polémica en la prensa entre Cardigondis del Coto Marin de Carriere, el legado de Fray Cipriano de la Santísima Trinidad (seudónimo del Padre Francisco Castañeda) y el editor de la Gaceta Ministerial. No sorprende, pues, que se denuncie a algunos eclesiásticos de oficiar de inquisidores de la opinión pública. ${ }^{119}$

Lo cierto es que a pesar de que hubo quienes consideraron al teatro una escuela del demonio, tras la declaración de la Independencia se crea, bajo el decreto del Director Supremo Juan Martín de Pueyrredón, la Sociedad del Buen Gusto del Teatro con el propósito de difundir los valores revolucionarios. La primera pieza dramática que estrena la Sociedad, nada menos que para la ocasión de la celebración del día de Santa Rosa de Lima considerada patrona de la revolución americana, es Cornelia Barroquia o la víctima de la Inquisición escrita por el español Luis Gutiérrez. ${ }^{120}$ Se trataba de una pieza condenada por la Inquisición, cuya difusión en Buenos Aires coincide, además, con la aparición de la obra de J. A. Llorente Historia crítica de la Inquisición de España, que se difundirá luego en el Río de la Plata.

Cornelia narra el drama de una mujer, hija del gobernador de Valencia, que es secuestrada por el Arzobispo de Sevilla y llevada a los calabozos de la Inquisición, donde el religioso abusa de ella. Si bien el guión de la representación rioplatense se ha perdido, se han podido conservar las crónicas de su puesta en escena. Mediante ellas sabemos que la obra abre paso a la crítica a cualquier tipo de persecución religiosa y a los clérigos que intentan constituirse en árbitros absolutos de la conciencia.

El texto original de la pieza denuncia la alianza entre la política y la religión y reivindica a un Dios tolerante. Lo cierto es que la obra seguramente fue adaptada. Como se ha registrado en las crónicas dedicadas al estreno, aquí el personaje del Arzobispo de Sevilla es reemplazado por un fraile dominico. De hecho, resulta curioso que la representación porteña haya decidido cambiar el triste final de la obra de Gutiérrez, en que Cornelia muere en las Ilamas, por el rescate de la joven a manos del poder político.

118 Ibídem: 353.

119 Por ejemplo, véase: “Carta remitida por Cardigondis del Coto Marin de Carriere", en El Censor N¹5, 30-11-1815. "Artículo comunicado", en Gaceta de Buenos Aires N³2, 2-12-1815. La Prensa Argentina, N¹4, 12-12-1815; La Prensa Argentina, N¹5, 19-12-1815.

120 Consultamos aquí: Gutiérrez, L. 1818. Cornelia Barroquia. Madrid: Chez Dennée. Cuarta edición, revista, corregida y aumentada. 
En un contexto crispado por la crítica del episcopado hacia la obra, vemos intervenir a Henríquez en la polémica. En El Censor, que se encontraba por entonces bajo su dirección, el fraile realiza las crónicas de la representación de la obra, afirmando: «el tribunal de la inquisición era presentado con todos sus horrores y en la plenitud de sus sombras». ${ }^{121}$ Pero, continúa, en la obra también se pudo oír «la voz santa de las leyes y los corazones se inundaron de celestial alegría ante la intervención saludable de la autoridad civil». ${ }^{122}$ Como sostiene L. Pradenas, para Henríquez la política y la ciencia relevan del mundo de la razón y no de aquel de la divinidad, como lo pretende el espíritu teocrático colonial español. ${ }^{123}$

Es en los propios escritos dramáticos del fraile revolucionario donde reaparece la crítica a la Inquisición, acompañada, una vez más, del elogio a las virtudes del gobierno norteamericano. Su primera pieza presentada ante la Sociedad del Buen Gusto se titula Camila o la Patriota de Sud América. ${ }^{124}$ La obra se sitúa en el complejo escenario de Quito tras el movimiento juntista que, recordemos, había presenciado Henríquez. La trama comienza tras la represión al mando de las tropas virreinales que sufre la primera junta provisional del gobierno que había decidido sustituir al Virrey. Como reacción ante la represión se produce un levantamiento popular que busca liberar a los patriotas que, luego de haber sido interrogados bajo el tormento, habían sido condenados a muerte. La protagonista, Ilamada Camila, es una criolla quien, imaginando que el destino de su marido, Diego, fue el asesinato en la represión, decide escaparse, junto a su familia, en una aldea omagua en medio de la selva amazónica. Allí se encuentra con el cacique de la tribu quien le ofrece protección bajo la condición de que se transforme en la esposa de su primer ministro. Sucede que el Cacique dice reproducir en su tribu un gobierno de estilo jeffersoniano, adoptando así características del gobierno norteamericano. De hecho, Yari, un indio de la tribu, no duda en nombrar a su aldea como "la nueva Filadelfia".

El cacique amenaza, entonces, a Camila y su familia con entregarlos a los españoles si no aceptan la unión matrimonial. Sin embargo, Camila, fiel a su marido, se rehúsa desconociendo que Diego había logrado sobrevivir y que, al igual que ella, decidió buscar protección en la aldea. Tras comprobar la fidelidad de la joven, el cacique le revela la verdad propiciando el encuentro entre Camila y Diego, sellándose así una alianza entre patriotas.

A lo largo de la pieza se evidencia una crítica al gobierno español no sólo a través de las voces de los personajes criollos sino también de los indios. Se evoca reiteradamente las crueldades de los tiranos apelando a la represión sufrida por Tupac Amaru y a los procesos de la Inquisición. Así, por ejemplo, Don José, padre de Camila, afirma: "Los tiranos están armados, no sólo de la fuerza, sino también del arma terrible de la superstición». ${ }^{125}$ Por su parte, el Cacique no duda en afirmar que "hombres perversos han hecho creer

121 El Censor N ${ }^{\circ} 103,4-9-1817: 2$.

122 El Censor N¹03, 4-9-1817: 3.

123 Pradenas 2006: 136.

124 Henríquez, C. 1817. Camila o la Patriota de Sud América. Buenos Aires: Imprenta Benavente y Ca. Consultado en: Biblioteca digital Memoria chilena de la Biblioteca Nacional de Chile.

125 Ibídem: 13. al Rey de España que los quemadores y los amigos de los quemadores son las columnas de su trono». ${ }^{126}$

La crítica a la persecución inquisitorial reaparece, aunque de modo implícito, en el personaje de Camila, quien le entrega al Cacique una carta con una serie de proposiciones acerca de las reformas que necesita América, entre las que se encuentra la tolerancia. En sus propuestas Camila elogia decididamente los principios liberales de gobierno. Así, su fidelidad y sus ideas la convierten, hacia el final de la obra, en una verdadera patriota de Sud América. Si Camila ofrece un modelo para las patriotas, la aldea omagua ofrece un modelo de gobierno basado en los principios liberales de Norteamérica.

Un argumento similar es el que se encuentra en su obra La inocencia en el asilo de las virtudes. ${ }^{127}$ La pieza cuenta la historia de un hombre inglés, Mr. Faber, que abandonó a su familia ya que, presumía, que su esposa le había sido infiel. El personaje decide refugiarse en Filadelfia. Allí conoce a otros hombres que, al igual que él, encontraron en Filadelfia un gobierno virtuoso. El desenlace de la historia se da, también aquí, con el reencuentro de Mr. Faber con su esposa e hijas que en busca del padre de familia decidieron emprender una travesía por América. El itinerario del viaje es interesante puesto que le permite al fraile condenar a las regiones fieles a España y elogiar a aquellas emancipadas. Se trata de una travesía plagada de peligros puesto que, en aquellas regiones controladas por los españoles, las mujeres son perseguidas por la Inquisición bajo el grito de: «todas estas son judías, son patriotas». ${ }^{128}$

Henríquez denuncia así el hecho de que los realistas acusen a los patriotas de herejes judaizantes. La asociación de España con el fanatismo es recurrente. Finalmente las mujeres logran refugiarse bajo el gobierno de Pétain quien las ayuda a llegar a Filadelfia donde estarán a salvo. Se representa, así, a Filadelfia como el asilo de las virtudes. La trama, pues, se repite. España es la contracara de los Estados Unidos y la emancipación americana es elogiada y llamada a seguir los pasos del país del norte. Si bien en la obra hay una crítica a la intolerancia hay también una defensa del cristianismo. De hecho, el personaje responsable de causar la separación de la familia es un judío que se arrepiente de sus engaños sólo cuando se convierte al cristianismo. La crítica a la Inquisición cede espacio aquí a la tolerancia sólo entre cultos cristianos. Es que, finalmente, Fray Henríquez busca reforzar la asociación de la revolución con el cristianismo.

Ahora bien, sus dos obras dramáticas fueron rechazadas por la Sociedad del Buen Gusto ya que sus miembros dudaron de la calidad del texto. Pero, además, se criticó el autoelogio que Camilo propiciaba en sus obras. Es que de hecho el nombre de la protagonista Camila Shkinere era un juego de palabras que aludía al propio autor. Lo cierto es que el fraile defendió sus obras dejando entrever la sospecha de que fueran sus ideas las que causaban rechazo.

Ante el hecho de no poder ver representadas sus piezas, las difunde a través del diario El Censor para lograr

126 Ibídem: 29.

127 Henríquez, C. 1817-1818. La inocencia en el asilo de las virtudes. Manuscrito consultado en: Biblioteca digital Memoria chilena de la Biblioteca Nacional de Chile.

128 Ibídem: $\mathrm{s} / \mathrm{n}$. 
suscripciones para su impresión. ${ }^{129}$ Pero las críticas no desistirán. Desconocemos cuántos ejemplares se dieron a la venta. Sin embargo, lo que podemos confirmar es que, al igual que en sus ensayos políticos, la crítica a la Inquisición y la difusión de los principios liberales tuvieron su espacio en las obras de ficción. Pues, como afirmaba el fraile, «el teatro debe respirar odio a la tiranía, amor a la libertad y, en fin, máximas liberales». ${ }^{130}$

En ese mismo año de 1817, Monteagudo regresa al Río de la Plata con el permiso del Director Supremo bajo la condición de no permanecer en Buenos Aires. Como se sabe, se incorporará en los ejércitos al mando de San Martín y O’Higgins. Será Monteagudo, y no Henríquez, quien esté presente en Santiago al momento de la redacción del Acta de Independencia. Hacia 1820 ambos revolucionarios inician una nueva etapa de su itinerario político e intelectual. El exilio transformó a Monteagudo, quien presenciando una Europa convulsionada por las luchas liberales, moderará sus posiciones. Así, será él quien explique su defensa ferviente por la república y la democracia de la primera década revolucionaria como una "fiebre mental". La construcción de un poder estable, encausado en una monarquía constitucional, será el proyecto que buscará poner en práctica durante el Protectorado de San Martín en Lima. El hombre que después del exilio viste a la europea, será ahora portador de un liberalismo moderado que lo llevará a descalificar a la revolución iniciada por R. Riego en la Península como extremadamente liberal. Monteagudo, finalmente comprometido con el proyecto bolivariano, se convertirá en un impulsor de la federación americana. Por su parte, Henríquez logrará regresar a Chile donde, abandonando ya el hábito de fraile, participa activamente de la vida política buscando hacer realidad sus proyectos forjados en los primeros años de la revolución. ${ }^{131}$

Por ese entonces las provincias del Río de la Plata se enfrentaban a nuevos desafíos y la ciudad de Buenos Aires pronto vería amenazado su predominio como centro de poder. Pero nuestros actores se encontraban ya fuera de ese escenario.

\section{CONCLUSIÓN}

La crisis de la Monarquía Hispánica transcurre en un escenario cambiante. Nuevos principios de legitimidad del poder surgen y nuevos actores salen a la búsqueda de esa legitimidad. La actividad política se reinventa y los hombres se lanzan precipitadamente a la aventura revolucionaria. Una aventura que reactualiza el problema teológico-político. Así, en el contexto de las revoluciones hispánicas, la Inquisición española emerge como un problema común que no sólo será debatido intensamente en la Península sino también en Hispanoamérica.

Hemos procurado recuperar aquí algunos de los escritos en los que Monteagudo y Henríquez dejaron plasmadas sus reflexiones a propósito del Santo Oficio. Se trata de dos

129 El Censor, Nº114, 20-11-1817.

130 Pradenas 2006: 136.

131 Entre ellos, ejerce como bibliotecario de la Biblioteca Nacional, funda El Mercurio de Chile y trabaja en las leyes a propósito de la educación, la sanidad pública y la abolición de la esclavitud. revolucionarios que se comprometieron, aunque con trayectorias diversas, en la difusión de las ideas herederas de la ilustración y forjadoras del naciente liberalismo hispánico y que, durante la época colonial, sufrieron la censura inquisitorial que buscaba dominar las conciencias. Dos revolucionarios que compartieron también un mismo espacio de sociabilización política como lo era la Logia Lautaro. Pero sus diferencias de vida también marcaron el final de su existencia. Ambos mueren en 1825. Monteagudo procurando llevar adelante el proyecto bolivariano es asesinado por encargo en la convulsionada Lima, Henríquez muere en la tranquilidad de Santiago.

Hemos visto que el proceso revolucionario habilita un nuevo espacio para la crítica político-religiosa. La crítica al Rey y al Inquisidor, allí cuando aparece, cede lugar a la defensa de los derechos naturales del hombre y a un orden político que se imagina como liberal. En sus escritos lo liberal se identifica con nuevas prácticas políticas asociadas a la libertad de pensamiento y expresión, a la publicidad de los actos de gobierno y a la sanción de una constitución. El orden liberal es imaginado como la antítesis del Antiguo Régimen.

Tanto en la prensa como en la literatura, encontramos una fuerte crítica a la Inquisición. Si la representación de la Inquisición como símbolo de despotismo, arbitrariedad y fanatismo será funcional a la lucha de los liberales peninsulares contra los proyectos absolutistas, en el Río de la Plata esa misma representación tendrá un mayor alcance. Puesto que es la arbitrariedad de la metrópolis la que se cuestiona, el tribunal se identifica con la Península misma. Pero en sus escritos la crítica al Santo Oficio no era un mero recurso para atacar a España. Era, también, un medio para imaginar posibles formas de articular religión y política. Así, mientras Monteagudo advertía que no se debía confundir la crítica a la alianza del trono y el altar con la condena hacia la religión, Henríquez no dudaba en elogiar las virtudes de Norteamérica como tierra de libertad y tolerancia. Las revoluciones holandesa y norteamericana constituían, la mayoría de las veces, el espejo en el que los actores buscaban reconocerse.

Es que la crítica a la Inquisición encierra una reflexión sobre el origen mismo de la soberanía. Desde las filosofías de la revolución se buscaba crear nuevas condiciones para el despliegue de la acción humana. El nuevo principio de legitimidad del poder desplazaba a Dios hacia otro lugar en la escena. La condena a las figuras del Rey y el Inquisidor vehiculizaba la reivindicación del rol de la voluntad humana en la construcción del orden político. Un orden en el que los derechos del hombre se concebían como punto de partida. Pero la defensa de los derechos del hombre se identificaba, una y otra vez, con la defensa de los valores cristianos encarnados en el Ser Supremo.

Se intentaba distinguir la religión de la política, aun cuando no se renunciara hacer un uso político de la misma. En este sentido, si bien es posible identificar el peso de la herencia regalista, la ruptura se hace presente en cuanto se hace posible comenzar a distinguir al ciudadano del creyente. Aun incluso cuando la libertad religiosa tarde en sancionarse. Es que mientras el cuestionado tribunal buscaba construir fieles que se comportasen como súbditos, desde sus escritos ambos revolucionarios llamaban al ejercicio de las virtudes ciudadanas. La prensa y el teatro se concebían 
como escuelas de la moral. Allí, en "el espejo de la virtud y el vicio", como solía decir el poeta Vera y Pintado, se buscaba proseguir la lucha revolucionaria con armas de papel.

Tras la independencia, el desafío de conjugar derechos y obligaciones en un sistema liberal suponía lograr una "obediencia gustosa". La pedagogía cívica debía cumplir ese objetivo pues se consideraba que la "República de las letras" era el fundamento de la "República de las leyes". El problema de la construcción de un orden político suponía también incertidumbres: ¿Cómo construir poder y a la vez limitarlo? ¿Cómo definir los alcances de la soberanía popular? ¿Cómo gobernar en la guerra de opinión? ¿Qué lugar otorgarle a Dios en la ciudad de los hombres?

Los desafíos de regular el orden social seguían vigentes. Se comprende entonces que los debates en torno a la libertad de expresión no cesaran ya que no lo hicieron los intentos por regularla. Se comprende también que una vez suprimida la jurisdicción del Santo Oficio en el Río de la Plata, el accionar inquisitorial se identifique con un modo de pensar lo político y hacer política. Un modo de accionar del cual no estaban exentos los propios revolucionarios. Pero, fundamentalmente, no sorprende que los revolucionarios concibieran la causa de la libertad como un aprendizaje político y a la práctica inquisitorial como su enemiga. Y es que el espíritu inquisitorio se percibía como una amenaza de posible despotismo en el futuro e incierto escenario del Río de la Plata.

\section{FUENTES}

Archivo del Arzobispado de Córdoba, Legajo N¹8, Tomo 3.

Archivo General de la Nación, Colección Andrés Lamas, Legajo N³3, Impreso sobre los libros prohibidos por la Inquisición (1798).

Dictamen del Doctor D. Antonio José Ruiz de Padrón, Ministro calificador del Santo Oficio, Abad de Villamartin de Valdeorres, y diputado en Cortés por las Islas Canarias, que se leyó en la Sesión Pública de 18 de Enero sobre el Tribunal de la Inquisición, Reimpreso en la Oficina de Don Antonio Rodríguez, Coruña, 1813. Disponible en el repositorio digital "Europeana Collections".

El Censor (1815). Ejemplares disponibles en la Biblioteca Digital Trapalanda de la Biblioteca Nacional Mariano Moreno.

El Duende político, $\mathrm{N}^{\circ} 4$, 1811, Cádiz, Imprenta de Don Manuel Santiago de Quintana. Consultado en Hemeroteca digital Memoria de Madrid.

El grito del Sud, Tomo Primero, Año 1812, Buenos Aires, Imprenta de Niños Expósitos. Colección disponible en la Biblioteca Digital Trapalanda de la Biblioteca Nacional Mariano Moreno.

El Independiente (1815). Ejemplares disponibles en la Biblioteca Digital Trapalanda de la Biblioteca Nacional Mariano Moreno.

El Monitor Araucano, N41 (10-7-1813), N48 (27-7-1813), Nº 91 (9-11-1813) y N 53 (17-6-1814). Disponibles en: Biblioteca digital Memoria chilena de la Biblioteca Nacional de Chile.

El Redactor de la Asamblea (1813). Reproducción facsimilar en: Junta de Historia y Numismática americana, Buenos Aires, 1913.

«El triunfo de la naturaleza, tragedia en cinco actos originalmente escrita en verso portugués por el Doctor Vicente Pedro Nolasco de Acuña, vertida en prosa castellana para el teatro de Buenos Aires. Imprenta de Niños Expósitos, Buenos Aires, 1814», en La Revolución de Mayo a través de los impresos de la época, Primera Serie, 1809-1815, Tomo VI, 1814-1815, BA: Comisión Nacional Ejecutiva del $150^{\circ}$ Aniversario de la Revolución de Mayo/AGN, 1967.

Gaceta de Buenos Aires- y Gaceta Ministerial- (1810-1813), reimpresión facsimilar, Junta de Historia y Numismática (dir.), Buenos Aires, Compañía Sudamericana de billetes de banco, 1911 (Tomo III).
Gutiérrez, L. 1818. Cornelia Barroquia. Madrid: Chez Dennée. Cuarta edición, revista, corregida y aumentada.

Henríquez, C. 1817. Camila o la Patriota de Sud América. Buenos Aires: Imprenta Benavente y Ca. Consultado en: Biblioteca digital Memoria chilena de la Biblioteca Nacional de Chile.

Henríquez, C. 1817-1818. La inocencia en el asilo de las virtudes. Manuscrito consultado en: Biblioteca digital Memoria chilena de la Biblioteca Nacional de Chile.

La Aurora de Chile, N¹3 (7-5-1812), №15 (21-5-1812), N¹7 (4-61812) y N³1 (10-09-1812). Disponible en: www.auroradechile.cl

"La Prensa Argentina», reproducción facsimilar en Biblioteca de Mayo: colección de obras y documentos para la Historia Argentina, Vol. 7, Buenos Aires, Senado de la Nación, 1960-1963.

Lafond du Lucy, G. 1911 [1853]. Viaje a Chile: Santiago de Chile: Imprenta universitaria.

Manifiesto que hace a las naciones el Congreso General Constituyente de las Provincias Unidas del Río de la Plata, sobre el tratamiento y crueldades que han sufrido de los españoles, y motivado la Declaración de su Independencia (25 de octubre de 1817)

Mártir o libre, reimpresión facsimilar, Museo Mitre (dir.), Buenos Aires, 1910.

Núñez, I. 1898. Noticias históricas de la República Argentina, Obra póstuma, Segunda Edición aumentada y corregida por el hijo del autor Sr. Don Julio Núñez. Buenos Aires: Litografía, Imprenta y Encuadernación de Guillermo Kraft.

Observaciones acerca de algunos asuntos útiles, Buenos Aires, Imprenta de Niños Expósitos/Imprenta Gandarillas y Socios, 1815, (Reproducción digital en Google books)

Oración fúnebre que en las exequias del católico rey Don Carlos III, celebradas en esta Santa Iglesia Cathedral de Cordova del Tucumán dixo el Doctor Don Gregorio Funes, Canónigo de Merced de la misma Santa Iglesia. Buenos Ayres MDCCXC. Con el Superior permiso, en la Real Imprenta de los Niños Expósitos. Reproducción facsimilar en: Archivo del Dr. Gregorio Funes. Deán de la Santa Iglesia Catedral de Córdoba 1944, Tomo I. Buenos Aires: Imprenta de la Biblioteca Nacional.

Oración inaugural pronunciada en la apertura de la Sociedad Patriótica la tarde del 13 de enero de 1812. Año tercero de la libertad de la America del Sud por el ciudadano Don José Bernardo de Monteagudo, Imprenta de Niños Expósitos, Buenos Aires. Disponible en la Biblioteca Digital Trapalanda de la Biblioteca Nacional Mariano Moreno.

"Sermón de Santo Domingo de Guzmán, predicado en el día de su fiesta por el M.R.P. M. Ex - Provincial F. Isidoro Celestino Guerra del Orden de Predicadores, Imprenta de Gandarillas y Socios, Buenos Aires, 1815", en La Revolución de Mayo a través de los impresos de la época, Primera Serie, 1809-1815, Tomo VI, 18141815, BA: Comisión Nacional Ejecutiva del $150^{\circ}$ Aniversario de la Revolución de Mayo/AGN, 1967.

\section{BibliografíA}

Amunátegui, M. L. 1889. Camilo Henríquez. Santiago: Imprenta Nacional. Alonso Tejada, L. 1969. Ocaso de la Inquisición en los últimos años del reinado de Fernando VII. Juntas de Fe, Juntas Apostólicas, Conspiraciones Realistas. Madrid: Zero.

Ayllón, F. 1997. El tribunal de la Inquisición: de la leyenda a la historia. Lima: Ediciones del Congreso del Perú.

Bosch, M. G. 1910. Historia del teatro en Buenos Aires. Buenos Aires: Establecimiento Tipográfico de El Comercio.

Botana, N. 2007. «El primer republicanismo en el Río de la Plata, 18101826», en I. Álvarez Cuartero y J. Sánchez Gómez (eds.), Visiones y Revisiones de la Independencia Iberoamericana. La Independencia de América: La Constitución de Cádiz y las Constituciones Iberoamericanas: 157-170. Salamanca: Ediciones Universidad de Salamanca.

Calvo, N. 2004. «Lo sagrado y lo profano. Tolerancia religiosa y ciudadanía política en los orígenes de la república rioplatense». Andes 15: 151-182. 
Calvo, N. 2006. «Los unos y los otros. Católicos, herejes, protestantes, extranjeros. Alcance de la tolerancia religiosa en el Río de la Plata durante las primeras décadas del siglo XIX». Anuario Instituto de Estudios Histórico-Sociales 21: 13-55.

Carozzi, S. 2011. Las filosofías de la revolución. Mariano Moreno y los jacobinos rioplatenses en la prensa de Mayo: 1810-1815. Buenos Aires: Prometeo.

Carvacho, R. M. y Dedieu, J. P. 2002. «Entre histoire et mémoire. L'Inquisition à l'époque moderne : dix ans d'historiographie». Annales. Histoire, Sciences Sociales, 57e année, 2: 349-372.

Casado, M. A. y La Parra López, E. 2013. La Inquisición en España agonía y abolición. Madrid: Akal.

Cebrelli, A. 2000. «Una herencia conflictiva: el imaginario religioso colonial y la construcción de las identidades nacionales». Andes 11: 1-43.

De la Torre Villar, E. 1989. "Minorías religiosas en la novela mexicana del siglo XIX». Estudios de Historia Moderna y Contemporánea de México 12: 63-78.

Di Stefano, R. 2000. «De la cristiandad colonial a la Iglesia nacional. Perspectivas de investigación en historia religiosa de los siglos XVII y XIX». Revista Andes 11: 83-113.

Di Stefano, R. 2007. «El púlpito anticlerical. Ilustración, deísmo y blasfemia en el teatro porteño postrevolucionario (1814-1824)". Itinerarios, Anuario del Centro de Estudios, "Espacio, memoria e identidad" (CEEEMI), I, 1: 183-227.

Di Stefano, R. 2010. Ovejas negras: historia de los anticlericales argentinos. Buenos Aires: Sudamericana.

Di Stefano, R. 2012. «Liberalismo y religión en el siglo XIX hispanoamericano. Reflexiones a partir del caso argentino», en Congreso Liberalism and Religión: Secularisation and the Public Sphere in The Americas. London: Senate House. (Disponible on-line: http:// sas-space.sas.ac.uk/4121/)

Di Stefano, R. y Martínez, I. 2011. «Frailes de gorro frigio. La experiencia de la Comisaría General de Regulares en el Río de la Plata (1813-1816)», en E. Torres (Coord.), Los dominicos insurgentes y realistas, de México al Río de la Plata: 147-181. México D. F. Instituto Dominicano de Investigaciones Históricas Miguel Ángel Porrúa.

Di Stefano, R. y Zanatta, L. 2000. Historia de Ia Iglesia argentina. Desde la Conquista hasta fines del siglo Xx. Buenos Aires: Grijalbo.

Dofour, G. 2005. «¿Cuándo fue abolida la Inquisición en España?». Cuadernos de llustración y Romanticismo 13: 93-107.

Edwards, A. 1934.Camilo Henríquez. Santiago: Prensas de la Universidad de Chile.

Elorza, A. 1989. El temido árbol de la libertad. España y la Revolución Francesa: 69-117. Barcelona: Aymes.

Escudero, J. A. 2005. Estudios sobre la Inquisición. Madrid: Marcial Pons.

Farberman, J. 2005. Las salamancas de Lorenza. Magia, hechicería y curanderismo en el Tucumán colonial. Buenos Aires: Siglo XXI.

Fernández Sebastián, J. (dir.) 2009. Diccionario político y social del mundo iberoamericano. Conceptos políticos en la era de las revoluciones, 1750-1850, Tomo I. Madrid: Centro de Estudios Políticos y Constitucionales.

Fernández Sebastián, J. 2011. «Toleration and freedom of expression in the Hispanic word between enlightenment and liberalism». Past and Present 211:159-197.

Fernández Sebastián, J. (coord.) 2012. La aurora de la libertad: los primeros liberalismos en el mundo iberoamericano. Madrid: M. Pons Historia.

García Cárcel, R. 1996. "Veinte años sobre la historiografía de la Inquisición». Publicaciones de la Real Sociedad económica de amigos del país: 231-254.

Goldman, N. 2000. «Libertad de imprenta, opinión pública y debate constitucional en el Río de la Plata (1810-1827)». Prismas. Revista de historia intelectual 4: 9-20.

Goldman, N. (dir.) 2008. Lenguaje y revolución. Conceptos políticos clave en el Río de la Plata, 1780-1850. Buenos Aires: Prometeo Libros.
Goldman, N. 2009. "La Revolución de Mayo: Moreno, Castelli y Monteagudo. Sus discursos políticos». Revista de la Universidad Católica Boliviana 22-23: 321-351.

González Bernaldo de Quirós, P. (Comp.) 2015. Independencias iberoamericanas. Nuevos problemas y aproximaciones. Buenos Aires: Fondo de Cultura Económica.

Guibovich Pérez, P. 2013. Lecturas prohibidas: la censura inquisitorial en el Perú tardío colonial. Lima: Fondo Editorial Pontificia Universidad Católica.

Halperín Donghi, T. 1985. Tradición política española e ideología revolucionaria de mayo. Buenos Aires: CEAL.

Hampe Martínez, T. 1998. Santo Oficio e historia colonial: aproximaciones al Tribunal de la Inquisición en Lima, 1570-1820. Lima: Ediciones del Congreso de Perú.

Hampe Martínez, T. 2004. «Ricardo Palma: cronista de la Inquisición». Quaderni ibero americani: Attualità culturale della Penisola Iberica e dell'America Latina 95: 15-30.

Herrero, F. (recop.) 2006. Bernardo Monteagudo. Revolución, independencia, confederacionismo. Buenos Aires: Grupo Editor Universitario.

Jaksic, I. y Posada Carbó, E. 2011. Liberalismo y poder. Latinoamérica en el siglo XIX. Santiago de Chile: Fondo de Cultura Económica.

Julliot, C. 2010. Le grand inquisiteur, naissance d'une figure mythique au XIX siècle. Paris: Honoré Champion Éditeur.

Kamen, H. 1985. La Inquisición española. México D. F.: Grijalbo.

La Parra López, E. 2014. «Intransigencia y tolerancia religiosa en el primer liberalismo español». Mélanges de la Casa de Velázquez 44-1: 45-63.

Lea, C. 1908. The inquisition in the Spanish dependencies. New York: Macmillan.

Lefort, C. 1986. Essais sur le politique XIX-XX siècles. Paris: Seuil.

Lewin, B. 1956. Supresión de la Inquisición y libertad de cultos en la Argentina. La Plata: Universidad Nacional de La Plata, Facultad de Humanidades y Ciencias de la Educación, Cuadernos de Extensión universitaria, Departamento de Filosofía, Instituto de Filosofía y del pensamiento argentino.

López Vela, R. 1990. «Inquisición y Estado. Los fundamentos historiográficos de una interpretación política (1930-1990)». Chronica nova 18: 267-342.

López Vela, R. 2005. «Inquisición, protestantes y Felipe II en 1851. Adolfo de Castro y la historia nacional como leyenda negra». Cuadernos de llustración y Romanticismo 13: 171-199.

Manent, P. 1993. "Christianisme et démocratie. Quelques remarques sur l'histoire politique de la religion, ou, sur l'histoire religieuse de la politique moderne», en P. Manent, P. Collin, P. Maraval, M. Lowy, J. M. Ferry y J. Rollet, L'Individu, le Citoyen, le Croyant: 53-74. Bruselas, Publications des Facultés Universitaires Saint-Louis.

Manent, P. 2001. Cours familier de philosophie politique. Paris: Fayard.

Manent, P. 2011. «Grandeza y miseria del liberalismo». Cuadernos de pensamiento político 30: 55-67.

Martínez Millán, J. 2007. La Inquisición española. Madrid: Alianza.

Mejías López, W. 1999. «El Tribunal del Santo Oficio y su sistema opresivo en América: herejía, sodomía y brujería en Santo Domingo, Puerto Rico y Cartagena de Indias en tres novelas latinoamericanas». Revista de crítica literaria latinoamericana 24, 49: 99-118.

Millar Carvacho, R. 1998. Inquisición y sociedad en el Virreinato del Perú: estudios sobre el Tribunal de la Inquisición de Lima. Santiago de Chile: Universidad Católica de Chile.

Ortemberg, P. 2011-2012. "Las vírgenes generalas: acción guerrera y práctica religiosa en las campañas del Alto Perú y el Río de la Plata (1810-1818)». Boletín del Instituto de Historia Argentina y Americana "Dr. Emilio Ravignani" 35/36: 11-41.

Palma, R. 1863. Anales de la Inquisición de Lima: Lima: Aurelio Alfaro impresor y encuadernador.

Pasino, A. 2013. «Buenos Aires-Cádiz-Londres: circulación y recepción sobre la legislación de la libertad de imprenta. (1810-1812)». PolHis 6-12: 83-94.

Peralta Ruiz, V. 2002. En defensa de la autoridad. Política y cultura bajo el gobierno del Virrey Abascal. Perú 1808-1816. Madrid: Consejo Superior de Investigaciones Científicas. 
Pérez Villanueva, J. y Escandell Bonet, B. (dirs.) 1984-2000. Historia de la Inquisición en España y América (3 Volúmenes). Madrid: Biblioteca de Autores Cristianos.

Pradenas, L 2006. El teatro en Chile: huellas y trayectorias. Siglos XVI a $x x$ : Santiago de Chile: LOM Ediciones.

Píriz García de la Huerta, F. 2012. Camilo Henríquez. El patriota olvidado. Santiago: RIL editores.

Prosperi, A. (dir.) 2010. Dizionario storico dell'Inquisizione, vol. 1. Pisa: Edizione della Normale.

Revuelta González, M. 2013. «Las dos supresiones de la Inquisición de la Inquisición durante la Guerra de la Independencia». Miscelánea Comillas 71-139: 221-263.

Roldán, D. 2007. «La historia del pensamiento político y la historia de lo político». Prismas 11: 177-182.

Rosanvallon, P. 2002. «Para una historia conceptual de lo político (nota de trabajo)». Prismas 6: 123-133.

Santini, B. 2012. "Traducciones y difusión de las ideas liberales, emancipadoras e ilustradas en los escritos del chileno Camilo Henríquez (1769-1825): defensa de las libertades, lucha por la independencia». Histoires de l'Amérique latine 7: 1-14.

Sarrochi Carreño, A. C. 2009. «La Inquisición como temática novelable en España e Hispanoamérica, o el intento de la literatura por luchar contra el silenciamiento de la Inquisición». The Hebrew University of Jeresulem 2-3: 108-125.

Sempere Muñoz, D. 2008. La Inquisición española como tema literario. Política, historia y ficción en la crisis del Antiguo Régimen. Londres: Tamesis Books.

Sempere Muñoz, D. 2010 «The abolition of the Inquisition and the creation of a historical myth». Hispanic Research Journal 11-1: 71-81.

Serrano, S. 2008. ¿Qué hacer con Dios en la República? Política y secularización en Chile (1845-1885). Chile: Fondo de Cultura Económica.
Silva Castro, R.1960. Escritos políticos de Camilo Henríquez. Santiago: Ediciones de la Universidad de Chile.

Soriano Muñoz, N. 2013. "En defensa de un pasado nacional: La Inquisición española en lucha por la memoria histórica de la Conquista». Cuadernos de Ilustración y Romanticismo 19: 281-301.

Ternavasio, M. 2003. "La visibilidad del consenso. Representaciones en torno al sufragio en la primera mitad del siglo XIX», en $\mathrm{H}$. Sábato y A. Lettieri (eds.). La vida política en la Argentina del siglo XIX. Armas votos y voces: 57-73. Buenos Aires: Fondo de Cultura Económica.

Ternavasio, M. 2010. «Política y cultura política frente a la crisis del orden colonial». Boletín del Instituto de Historia Argentina y Americana "Dr. Emilio Ravignani" 33: 39-53.

Ternavasio, M. 2013. «A doscientos años de la Asamblea del año XIII». PolHis 12: 67-72.

Toribio Medina, J. 1945. La Inquisición en el Río de la Plata. Buenos Aires: Huarpes.

Toribio Medina, J. 1956. Historia del Tribunal de la Inquisición en Lima (1569-1820). Santiago de Chile: Fondo Histórico y Bibliográfica Medina.

Toribio Medina, J. 1952. Historia del Tribunal del Santo Oficio de la Inquisición en Chile. Santiago de Chile: Fondo Histórico y Bibliográfico J. T. Medina.

Torres Puga, G. 2009. «Inquisidores en pie de guerra». Historia mexicana 59-1: 281-325.

Vasallo, J. 2010. Herejes, mujeres y viajeros en la Córdoba tardo colonial. Córdoba: Universitas.

Villarreal Brasca, A. 2009. «Bernardo de Monteagudo. Un americano revolucionario singular». Revista Complutense de Historia de América 35: 285-293. 